\title{
Motivasyon, Deneyime Açıklık ve Örgütsel Bağlılık: Değişime İlişkin Tutumların Aracılık Rolü
}

\author{
Sait Gürbüz \\ Ankara Sosyal Bilimler Üniversitesi
}

\author{
Mehmet Emin Bayık \\ Ankara Yıldırım Beyazıt Üniversitesi
}

\begin{abstract}
Özet
Bu çalışmada, değişime ilişkin tutumların öncüllerinin belirlenmesi ve söz konusu öncüller ile duygusal bağlllık arasındaki mekanizma olarak değişime ilişkin tutumların oynadığı aracılık rolünün incelenmesi amaçlanmıştır. Bu kapsamda, 783 çalışanın gönüllü katılımı ile anket çalışması yapılıış ve veriler varyans analizi ve yapısal eşitlik modellemesi (YEM) analizi ile test edilmiştir. Elde edilen bulgular neticesinde hizmet süresi, eğitim durumu, içsel iş motivasyonu, deneyime açılılk ve gelişme ihtiyacı gücünün değişime ilişkin tutumların öncülü olduğu; katılımcıların yaşının ise değişime ilişkin tutumlara etki etmediği belirlenmiştir. Değişime ilişkin tutumların, içsel iş motivasyonu, deneyime açıklık ve gelişme ihtiyacının gücü ile duygusal bağlılık arasındaki ilişkilerde aracılık rolü oynadığı tespit edilmiştir. Elde edilen bulgular ışı̆̆ında uygulamaya ve yazına yönelik öneriler ortaya konulmuştur.
\end{abstract}

Anahtar kelimeler: Örgütsel değişim, değişime ilişkin tutumlar, duygusal bağl1lık, içsel iş motivasyonu, deneyime açıklık, gelişme ihtiyacının gücü

\begin{abstract}
The aim of the current study was to identify the antecedents of attitudes towards change and to investigate the mediator role of attitudes towards change in the relationship between its antecedents and affective commitment. A sample of 783 participants voluntarily took the survey. The data were analyzed via analysis of variance and structural equations modeling. Tenure, education level, intrinsic motivation, openness to experience and growth need strength were found to be antecedents of attitudes towards change, while age was not. Attitudes towards change played a mediator role in the following relationships between openness to experience and affective commitment, intrinsic work motivation and affective commitment, and growth need strength and affective commitment. In light of the findings of the current study, practical and theoretical implications were discussed.
\end{abstract}

Keywords: Organizational change, attitudes towards change, affective commitment, intrinsic work motivation, openness to experience, growth need strength

Yazışma Adresi: Prof. Dr. Sait Gürbüz, Ankara Sosyal Bilimler Üniversitesi, Siyasal Bilgiler Fakültesi, İşletme Bölümü, 06030 UlusAltındağ / Ankara

E-posta: sait.gurbuz@asbu.edu.tr

Gönderim Tarihi: 19.09 .2018

Kabul Tarihi: 02.05.2019 


\section{“Derisini değiştirmeyen yılan, \\ kafasını değiştirmeyen insan ölmeye mahkûmdur."}

Friedrich Nietzsche

Nietzsche'nin sözünden yola çıkılarak denilebilir ki bireysel ve örgütsel düzeyde değişim kaçınılmazdır, süreklidir ve daha da ötesi gereklidir. Örgütler de açık sistem olarak çevreleri ile sürekli etkileşim içinde kalarak hayatta kalmaya çalışırlar. Bu nedenle örgütlerin yaşam evrelerinde de değişimin değişmeyen bir olgu olduğu ifade edilebilir (Bertalanffy, 1950).

Beer ve Nohria (2000) örgütsel değişim gayretlerinin \%70'inin başarısız olduğunu ifade etmektedir (karŞ1 fikirler için bkz. Hughes, 2011). Bu başarısızlıkların çoğu değişim görevlilerinin, bireylerin örgütlerde oynadığ1 kritik rolü ve özellikle bireylerin değişime ilişkin tutumlarını görmezlikten gelmelerinden veya önemsememelerinden kaynaklanmaktadır (Armenakis, Harris ve Mossholder, 1993; George ve Jones, 2001; Greenhalgh, Robert, Macfarlane, Bate ve Kyriakidou, 2004; Hall ve Hord, 1987; Isabella, 1990; Lau ve Woodman, 1995; Oreg, 2006). Oysa ki örgütsel değişim hem bir bütün olarak örgütü hem de bireysel olarak örgütün üyelerini ilgilendiren bir olgudur ve örgütü oluşturan tüm alt sistemlerde eşzamanlı olarak gerçekleşmesi gereken bir süreçtir (Vakola ve Nikolaou, 2005).

Örgütsel değişim gayretlerinin başarısı için çalışanların örgütsel bağlılık düzeyleri ile onların örgütsel bağlılıklarına etki eden psikolojik faktörler büyük öneme sahiptir (Coleman, Irving ve Cooper, 1999). Bu nedenle, bir örgüt yürüttügü örgütsel değişim gayretlerinin başarılı olmasını hedefliyorsa sadece örgütsel düzeyde (makro düzeyde) kavramlaşan olgulara odaklanmamalı; değişimin kendisini bizzat yaşayan örgüt mensuplarını ihmal etmekten uzak durmalı, çalışanları ve onların psikolojik süreçlerini (mikro düzeyi) de dikkate alan bir örgütsel değişim stratejisi oluşturmalıdır (Elias, 2009). Ancak, örgütsel değişimi konu alan araştırmalarda daha çok makro ve örgütsel düzeydeki faktörlerin ele alındığ 1 (örn., Judge, Thoresen, Pucik ve Welbourne, 1999; Vakola, Tsaousis ve Nikolaou, 2004), buna karşın çalışanların psikolojik süreçleri gibi mikro düzeydeki değişkenlerin göz ardı edildiği görülmektedir (Elias, 2009; Fedor, Caldwell ve Herold, 2006; Wanberg ve Banas, 2000). Örgütsel değişim gayretleri kapsamında çalışanların psikolojik süreçlerinin dikkate alınmamasının örgütsel değişim gayretlerinin başarısızlığa uğramasına neden olmasının ötesinde; örgütsel değişim, çalışanların stres ve sinizm düzeylerinin yükselmesine neden olması suretiyle uzun vadede onların örgütsel bağlılık, iş tatmini, örgüte güven ve motivasyonlarının azalmasına kadar giden olumsuz sonuçlar doğurabilmektedir (Reichers, Wanous ve Austin, 1997; Rush, Schoel ve Barnard, 1995; Schweiger ve DeNisi, 1991).

Örgütteki bireylerin değişime yönelik desteğinin kazanılması da örgütsel değişimin başarısı için ayrı bir önem taşımaktadır (Piderit, 2000). Örgütsel değişimin çalışanlar tarafından desteklenmesi için onların davranışlarına yön veren değişime ilişkin tutumlarının olumlu (istenen) yönde değiştirilmesi ve geliştirilmesi gerekmektedir (Antoni, 2004). Çalışanların değişime yönelik tutumları, örgütlerin yürüttükleri değişim gayretlerinin başarılı ya da başarısız olmasında kilit rol oynamaktadır (Elias, 2009). Örgütteki bireyler değişimi heyecan ve mutlulukla ya da korku ve endişe ile karşıllayabilirler (Vakola ve Nikolaou, 2005). Çalışanlar değişime yönelik olumlu tutum sahibi oldukları zaman örgütsel değişim faaliyetlerini desteklemekte ve kolaylaştırmakta; olumsuz tutum sahibi olduklarında ise değişime karşı direnmekte ve girişim gayretlerini sabote edebilmektedirler (Lines, 2005). Çalışanların gelişme ihtiyacının gücü, içsel iş motivasyonu ve deneyime açıklık gibi kişilik özelliklerinin ve bunların çalışanların değişime yönelik tutumlarını ne şekilde etkilediğinin belirlenmesinin, örgütsel değişim gayretlerinin önündeki engelleri kaldırmaya yardımcı olmakla birlikte bu gayretlere pozitif yönde ivme kazandırıcı etki yapacağı değerlendirilmektedir.

Mikro düzeydeki değişkenleri konu alan çalışmaların kısıtlı olması ve mikro düzey dinamiklere odaklanan araştırmalar yapılmasına yönelik ihtiyaçlar (Wanberg ve Banas, 2000), örgütsel değişim gayretlerinde çal1şanların psikolojik süreçlerini ele alan bir çalışmanın gerekliliğine işaret etmektedir. Türkçe alanyazında ise söz konusu değişkenlere ilişkin müstakil araştırmalar (örn., Gürbüz, Ayhan ve Sert, 2014; Wasti, 2002) olmakla birlikte örgütsel değişime ilişkin psikolojik süreçleri ele alan çalışmalara rastlanmamıştır. Buradan hareketle bu çalışmanın amacı; (a) çalışanların demografik özellikleri ile değişime ilişkin tutumları arasındaki ilişkileri belirlemek, (b) çalışanların gelişme ihtiyacının gücü, içsel iş motivasyonları ve deneyime açıklık özellikleri ile değişime ilişkin tutumları ve duygusal bağlılık düzeyleri arasındaki ilişkileri incelemek ve (c) çalışanların gelişme ihtiyacının gücü, içsel iş motivasyonları ve deneyime açıklık düzeyleri ile duygusal bağlılıkları arasındaki ilişkilerde çalışanların değişime ilişkin tutumlarının aracılık rolü olup olmadığını araştırmaktır. Bu çalışmanın değişim ve dönüşüm süreci devam ederken, çalışanların değișime yönelik tutumlarının incelenmesinin, bu tutumların örgütsel bağlılık düzeylerinde ne yönde bir etki (olumlu ya da olumsuz) yaptığının tespit edilmesinin ve buna bağlı olarak çalışanların örgütsel değişime yönelik tutumlarının öneminin ortaya koyulmasının yazına katk1 sağlaması beklenmektedir. 


\section{Kavramsal Çerçeve}

\section{Değişsime İlişskin Tutumlar}

Genel tutumlardan ziyade belirli tutumlar belirli davranışları daha iyi yordamaktadır (Eagly ve Chaiken, 1998; Fishbein ve Ajzen, 1975). Örgütsel değişim alanında da bireylerin değişime ilişkin tutumlarının değişimi destekleme veya değişimin karşısında direnme davranışlarını daha iyi yordayacağı düşüncesi ile örgüt üyelerinin değişime ilişskin tutumları üzerine odaklanılmıştır (Choi, 2011). Değişime ilișkin tutumlar; alanyazında değişime hazır olma, değişime karşı direnç, değişime ilişkin sinizm, değişime açıklık, değişimle başa çıkma, değişime uyum, değişimin benimsenmesi ve değişime bağlılık gibi farklı isimler altında ele alınmıştır (Armenakis ve ark., 1993; Bouckenooghe, Devos ve Van den Broeck, 2009; Chen ve Wang, 2007; Herscovitch ve Meyer, 2002; Lau ve Woodman, 1995; Oreg, 2003; Piderit, 2000; Reichers ve ark., 1997; Stanley, Meyer ve Topolnytsky, 2005; Terry ve Jimmieson, 2003; Wanberg ve Banas, 2000; Yousef, 2000). Değişime hazır olma; değişime ne derece ihtiyaç olduğuna ve örgütün değişim gayretlerini başarılı olarak yürütebilme kapasitesinin ne derecede mevcut olduğuna ilişkin olarak örgüt üyelerinin inanç, düşünce ve niyetleri olarak tanımlanmıștır (Armenakis ve ark., 1993). Değişime bağlılık; bireyleri değişim gayretinin başarılı bir şekilde uygulanması için gerekli olduğu değerlendirilen hareket tarzlarını uygulamaya zorlayan bir kuvvet olarak tanımlanmıştır (Herscovitch ve Meyer, 2002). Değişime açık olma, değişimi destekleme ve değişimin getireceği muhtemel sonuçlara ilișkin olumlu duygulara sahip olmadır (Devos, Buelens ve Bouckenooghe, 2007; Miller, Johnson ve Grau, 1994). Choi (2011) örgütsel değişim ile ilgili sinizmi de değişime ilişkin tutumlar içerisinde ele almıştır. Örgütsel değişim ile ilgili sinizm, değişim gayretlerinin başarılı olması ihtimaline ilișkin olarak kötümser olma ve bundan dolayı yönetimi suçlama olarak ifade edilmektedir (Brown ve Cregan, 2008; Reichers ve ark., 1997; Wanous, Reichers ve Austin, 2000). Bu farklı tanımlama ve yapılar bireylerin değişim karşısında direnme veya değişime destek olma davranışlarına yönelik bilişsel göstergeler olarak tanımlanmaktadır (Choi, 2011).

\section{Demografik Özellikler}

Grimm ve Smith (1991), genç yaştaki yöneticilerin değişen çevre koşulları karşısında değişime daha kolay adapte olmak suretiyle planlarını değiştirdiklerini tespit etmişlerdir. Yaş ilerledikçe değişime adapte olmanın ve değişimin gereklerini yerine getirmenin de giderek zorlanacağı ifade edilebilir. $\mathrm{Bu}$ nedenle; yaşın, değişime ilişkin tutumlar üzerinde negatif yönde etkili olması, çalışanların yaşının arttıkça değişime ilişkin tutumlarının olumsuz olması beklenmektedir.
Hipotez 1a: Yaş ile değişime ilişkin olumlu tutumlar arasında negatif ve anlamlı bir ilişki vardır.

Iverson (1996), çalışanların hizmet süresinin az olmasının onların değişime ilişkin tutumlarını pozitif yönde etkilediğini tespit etmiştir. Grimm ve Smith (1991), hizmet süresi daha düşük olan yöneticilerin kendi planlarını değiştirmek suretiyle değişime daha kolay adapte olduklarını belirlemişlerdir. Daha önce yapılmış çalışmaların bulgularından hareketle hizmet süresi arttıkça çal1şanların daha muhafazakâr olmaları ve değişime ilişkin olarak olumsuz tutumlar sergilemeleri beklenmektedir.

Hipotez $1 b$ : Hizmet süresi ile değişime ilişkin olumlu tutumlar arasında negatif ve anlamlı bir ilişki vardır.

Iverson (1996) çalışanların eğitim durumunun yüksek olmasının onların değişime ilişkin tutumlarını pozitif yönde etkilediğini tespit etmiştir. Cordery, Sevastos, Mueller ve Parker (1993) eğitim düzeyi ile değişimin kabullenilmesi arasında pozitif yönde ilişki olduğunu belirlemişlerdir. Vakola ve arkadaşları (2004) da eğitim düzeyi ile değişime ilişkin tutumlar asında pozitif yönde ilişki olduğunu ve eğitim düzeyi arttıkça çalışanların değişime ilişkin olumlu tutumlarının arttığını tespit etmişlerdir. Bu nedenle çalışanların eğitim durumuna göre değişime ilişkin tutumlarının farklılaşması, eğitim seviyesi arttıkça çalışanların değişime ilişkin olumlu tutumlarının da artması beklenmektedir.

Hipotez 1c: Değișime ilişkin tutumlar eğitim durumuna göre farklılık gösterir. Eğitim düzeyi arttıkça çalışanların değişime ilişkin olumlu tutumları da artar.

\section{Duygusal Bağlılık}

Örgütsel bağlılık ile ilgili alanyazında farklı tanımlama ve sınıflamalar olmasına rağmen en çok kabul gören sınıflamanın Allen ve Meyer'in (1990) duygusal bağlılık, devam bağlılı̆̆ ve normatif bağlılık olmak üzere üç boyut altında yaptığı sınıflama olduğu söylenebilir. Duygusal bağlılık çalışanların istedikleri için örgütte kaldıklarını, devam bağlılı̆̆ı çalışanların ihtiyaç duydukları için örgütte kaldıklarını ve normatif boyut ise çalışanların örgütte kalmak zorunda oldukları için örgütte kaldıklarını ifade etmektedir (Allen ve Meyer, 1990; Kartopu ve Gürbüz, 2016; Meyer ve Allen, 1991). Duygusal bağlılık; çalışanın duygusal olarak örgüte bağlanmasını ve örgütle bütünleşmesini, örgütte kalmak yönündeki arzusunu, örgütün amaç ve değerlerini benimsemesini ve örgüt yararına çaba sarf etmesini ifade etmektedir (Allen ve Meyer, 1990; Gürbüz ve ark., 2014; Wasti, 2002). Bu çalışmada, örgütsel bağlılığı işletimselleştirmek (operationalization) amacıyla örgütsel bağlılık ile ilgili çalışmalarda en çok kullanılan duygusal bağlılık boyutu ele alınmıştır.

Değişime ilişkin tutumların örgütsel bağlılık ile arasındaki ilişkinin kuramsal temeli bilişsel-fenomeno- 
lojik stres kuramı ile açıklanabilir (Lazarus, 1990, 2000). Söz konusu kurama göre bireyin stresli olaylara ilişkin bilişsel ve duygusal değerlendirmeleri, öznel iyi oluş başta olmak üzere birçok ardıla yol açmaktadır. Bu bağlamda, yaşanan bir değişime ilişkin çalışanların olumlu bir tutuma sahip olmaları hem değişim girişimini kolaylaştırabilir hem de yaşadıkları bu sürece ilişkin olumlu psikolojik ve duygusal deneyimler algılamalarına yol açabilir. Bununla birlikte, çalışanların değişime karşı güçlü bir olumsuz tutuma sahip olması değişim girişimlerine karşı koyma, bu girişimleri sabote etme gibi sonuçlara neden olabilecektir (Lines, 2005). Değișime ilișkin olumlu tutuma sahip çalışanlar, olumlu bilişsel ve duygusal süreçler deneyimleyeceklerinden dolayı bu durum onların örgüt bağlılıklarını da arttırabilecektir (Martin, Jones ve Callan, 2005). Alanyazında yapılan daha önceki çalışmalar örgütsel bağlılık ile değişime ilişkin tutumlar arasında pozitif ve anlamlı ilişkiler olduğuna işaret etmektedir (Elias, 2009; Kwahk ve Kim, 2008; Kwahk ve Lee, 2008; Madsen, Miller ve John, 2005; Martin ve ark., 2005; Yousef, 2000). Örneğin; çalışanların değişime ilişkin değerlendirmelerinin düzenleme göstergeleri olarak ele alınan öznel iyi oluş, iş tatmini ve örgütsel bağlılığ1 pozitif yönde etkilediği saptanmıştır (Martin ve ark., 2005). Söz konusu çalışmada değişime ilişkin öz-yeterlilik inançları ile değişimi kontrol algısının, bağlılığı pozitif yönde yordadığı raporlanmıştır. Elias (2009) ise çalışanların değişime ilişkin tutumlarının örgütsel bağl1lığ1 pozitif yönde etkilediğini tespit etmiştir. Söz konusu görgül bulgulardan hareketle şu hipotez önerilmiştir: Hipotez 2: Değişime ilişkin tutumlar ile duygusal bağl1lık arasında anlamlı ve pozitif bir ilişki vardır.

\section{İcsel İs Motivasyonu}

İçsel motivasyon, bir faaliyetin ikincil bir kazanç elde etmek yerine sadece söz konusu faaliyetten hoşlanılması nedeniyle yapılmasına yönelik motivasyon iken dışsal motivasyon bir faaliyetin çevresel faktörlerin zorlaması sonucu veya yapılan faaliyetten doğması beklenen ikincil bir kazanç elde etmek amaciyla söz konusu faaliyetin yapılmasına yönelik motivasyondur (Ryan ve Deci, 2000). Öz belirleme kuramına göre insanların kendi edimleri üzerinde kontrol sahibi olmak istemeleri nedeniyle bireysel olarak tercih edilen ve hoşlanılan bir edim, bireyler için zorunluluk haline dönüştüğünde bireylerin motivasyonları bundan negatif yönde etkilenmektedir (Ryan ve Deci, 2000).

İçsel motivasyon işle ilgili konulara uyarlandığında çalışanların bir işi yalnızca söz konusu işi yapmaktan hoşlandıkları için yapmaları ve söz konusu işi yaparken bu işin yapılmasından doğacak diğer faydaları gözetmeksizin o işi yapmaları olarak tanımlanabilir (Cerasoli, Nicklin ve Ford, 2014). Diğer bir deyişle içsel iş moti- vasyonu bir işin sadece sevildiği ve hoşlanıldığı için yapılmakta olması, dışsal iş motivasyonu ise yapılan işten gerçekten hoşlanılmamasına rağmen maddi getiri ve zorunluluk gibi nedenlerle yapılmakta olması olarak ifade edilebilir. Bireylerin yeni deneyimler arayışı içinde olmaları ve işlerine ilişskin ulaşmayı arzuladıkları yeni hedefler belirlemeleri onların içsel iş motivasyonu tecrübe etmelerini sağlamaktadır (Houkes, Janssen, de Jong ve Nijhuis, 2001). İçsel iş motivasyonu yüksek olan çalışanlar, kendilerinin yeteneklerini geliştiren bireysel hedefler belirleyerek kişisel gelişimlerine katkıda bulunan işlerden daha çok hoşlanırlarken; dışsal iş motivasyonu yüksek olan bireyler ilave gayret gerektiren, yeni bilgiler öğrenilmesini zorunlu kılan, kendilerini işe ilişkin belirsizliğe yönelten işlerden hoşlanmamaya meyillidirler (Amabile, Hill, Hennesy ve Tiger, 1994). Örgütsel değişim, çal1şanların yeni deneyimler yaşamalarına ve yeni hedefler belirlemelerine olanak sağladığ için içsel iş motivasyonu yüksek olan bireylerin değişime ilişkin tutumları da yüksek olmaktadır (Elias, 2009). İçsel iş motivasyonu düşük olan bireylerin ise işlerini gerçekten hoşlanarak yapmadıkları düşünüldüğünde örgütsel değişimin getireceği işe ilişkin ilave deneyimler yaşamak ve işe yönelik yeni hedefler belirleyerek bu hedefleri gerçekleştirme yönünde çaba sarf etmek istemeyecekleri ve değişime ilişkin olarak olumsuz tutumlar geliştirecekleri ifade edilebilir. Hipotez 3: İçsel iş motivasyonu ile değişime ilişkin tutumlar arasında anlamlı ve pozitif bir ilişki vardır.

Miller'e (2002) göre içsel iş motivasyonu yüksek olan çalışanlar, örgütlerine daha yüksek düzeyde bağl1lik göstermektedir. Mathieu ve Zajac (1990), içsel motivasyon ile örgütsel bağlılık arasında korelasyonel ilişki olduğunu belirlemişlerdir. Eby, Freeman, Rush ve Lance (1999), Moon (2000) ile Elias (2009) çalışanların içsel iş motivasyonuna sahip olmalarının, onların örgütlerine yönelik duygusal bağlılık göstermelerinde etkili olduğunu tespit etmişlerdir. Ayrıca Elias (2009) çalışanların içsel iş motivasyonları ile duygusal bağlılıkları arasında değişime ilişkin tutumların aracılık rolü oynadığını tespit etmiştir. Benzer şekilde; içsel iş motivasyonunun duygusal bağlılığa olumlu yönde etki etmesi ve bu ilişkide değişime ilişkin tutumların aracılık rolü oynaması beklenmektedir.

Hipotez 4: İçsel iş motivasyonu ile duygusal bağlılık arasındaki ilişkide değişime ilişkin tutumların aracılık rolü vardir.

\section{Deneyime Açıklık}

Beş Faktör kişilik özelliklerinden birisi olan deneyime açıklık; zekâ, kavrayış, yaratıcılık, hayal gücü, kültürlü olma, hoşgörü ve meraklılık gibi kişilik özellikleri ile ilişkilendirilmektedir (Barrick ve Mount, 1991; Goldberg, 1992). Deneyime açıklık düzeyi yüksek olan 
bireylerin yaratıcı ve soruşturmacı eğilimlerinin olması yenilikler ile daha fazla motive olabileceklerine işaret etmektedir (Penney, David ve Witt, 2011). Diğer yandan deneyime açıklık düzeyi yüksek olan bireylerin stresli olaylar ile başa çıkmada daha etkili yöntemler üretebilecekleri belirtilmektedir (McCrae ve Costa, 1986). Yapılan bir araştırmada deneyime açıklık düzeyi yüksek olan çalışanların, görev bağlamında yapılan değişiklikler karşısında deneyime açıklık düzeyi düşük olanlara göre daha iyi karar verebildikleri tespit edilmiştir (LePine, Colquitt ve Erez, 2000). Pulakos, Arad, Donovon ve Plamondon (2000) uyumsal performans açısından deneyime açıklık düzeyleri yüksek olan bireylerin daha başarılı olduğunu tespit etmişlerdir.

Örgütsel değişim ile ilgili olarak yapılan çalışmalarda da deneyime açıklık kişilik özelliği düzeyi yüksek olan çalışanların örgütsel değişime daha açık oldukları ortaya çıkmıştır. Örneğin; Judge ve arkadaşları (1999) yaptıkları araştırmada, deneyime açıklık düzeyinin yüksek olmasının, örgütsel değişim ile başa çıkma açısından pozitif yönde etki yaptığını tespit etmişlerdir. Vakola ve arkadaşlarının (2004) çalışmasında da çalışanların deneyime açıklık düzeylerinin yüksek olmasının değişime ilişkin tutumlarını pozitif yönde etkilediği belirlenmiştir. Deneyime açıklık düzeyi yüksek olan bireylerin zekâ, kavrayıș, yaratıcılık, hayal gücü, kültürlü olma, hoşgörü ve meraklılık gibi özellikleri dikkate alındığında değişime ilişkin tutumlarının deneyime açıklık düzeyi düşük olan bireylere göre daha pozitif yönde olması beklenmektedir.

Hipotez 5: Deneyime açıklık kişilik özelliği ile değişime ilişkin tutumlar arasında anlamlı ve pozitif bir ilişki vardir.

Deneyime açık olma, bireyin örgüt içi ve örgüt d1şında yeni iş alternatifleri araması yönünde eğilimi olarak da ifade edilebilir. Choi, Oh ve Colbert (2015), 50 farklı araştırmayı içeren meta-analiz çalışmasında beş faktör kişilik özelliklerinin tümünün duygusal bağlılık ile pozitif ilişkili olduğunu tespit etmişlerdir. Dolayısıyla söz konusu meta-analiz çalışmasının bulgularına paralel olarak, deneyime açıklık düzeyi yüksek olan çalışanların duygusal bağlılık düzeylerinin de yüksek olması beklenmektedir.

Hipotez 6: Deneyime açıklık kişilik özelliği boyutu ile duygusal bağlılık arasındaki ilişkide değişime ilişkin tutumların aracılık rolü vardır.

\section{Gelişme İhtiyacının Gücü}

İş karakteristikleri modelinin önemli bir parçası olan gelişme ihtiyacının gücü; çalışanların işyerinde kişisel başarı sağlama, yeni şeyler öğrenme ve kişisel gelişim düzeylerini artırma yönünde duydukları ihtiyacın derecesine ilişkin bir kişilik özelliğidir (Hackman ve Ol- dham, 1980). Gelişme ihtiyacının gücü yüksek olan bireyler açısından iş özellikleri (beceri çeşitliliği, görevin kimliği, görevin önemi, özerklik, geri bildirim) ile içsel iş motivasyonu, iş kalitesi ve iş tatmini arasındaki ilişkiler pozitif ve daha güçlü iken; gelişme ihtiyacının gücü düşük olan bireyler açısından söz konusu ilişkilerin kuvveti daha zayıftır (Hackman ve Oldham, 1980; Loher, Noe, Moeller ve Fitzgerald, 1985). İş zenginleştirmeleri kapsamında yapılan değişikliklerin yarattığı firsatlara; gelişme ihtiyacının gücü yüksek olan çalışanlar büyük bir hevesle tepki göstermekte iken, gelişme ihtiyacının gücü düşük olan çalışanlar bu firsatlara değer vermeyebilmekte ve hatta bunları bir firsattan ziyade kendileri açısından bir tehdit olarak algılayabilmektedirler (Houkes ve ark., 2001). Bu durum iş zenginleştirme faaliyetleri ile işlerde yapılan değişikliklerin, çalışanların tutum ve davranışları üzerinde etkili olabilmesi için bireylerin gelişme ihtiyacının gücü düzeylerinin önemini ortaya koymaktadır.

Başarılı bir değişim süreci içsel iş motivasyonu yüksek olan ve örgütsel değişimi bir öğrenme firsatı olarak gören çalışanlara ihtiyaç göstermektedir (Kouzes ve Posner, 2002). Gelişme ihtiyacının gücü; çalışanların işlerine yönelik kişisel gelişim ve değişime duydukları ihtiyaçlarının derecesi olarak, Kouzes ve Posner'in (2002) işaret ettiği örgütsel değișimi bir öğrenme firsatı olarak görme olgusu ile örtüşmektedir (Elias, 2009). Karmaşık ve zorlayıcı işlerin başarılabilmesi için çalışanların yüksek düzeyde gelişme ihtiyacının gücüne sahip olmalar1 gerekmektedir (Graen, Scandura ve Graen, 1986). Örgütsel değişim; bireysel gelişim ve ilave gayret gibi normal şartlarda görevin gerektirdiği edimlerin ötesinde çabalar gerektirdiğinden dolayı gelişme ihtiyacının gücü düşük olan bireyler örgütsel değişisme ilişsin olarak olumsuz tutum geliştirmektedirler (Elias, 2009). Bu düşünceye paralel olarak, gelişme ihtiyacının gücü yüksek olan bireyler ise örgütsel değişimin yarattığı yenilikçilik ortamını kişisel gelişim ve yeni bir şeyler öğrenme açısından bir firsat bilerek örgütsel değişimi destekleyen bir tutum sergileyebilirler. Fok, Hartman, Patti ve Razek (2000) gelişme ihtiyacının gücü düşük olan bireylerin, toplam kalite yönetimi uygulamalarına geçiş esnasında yapılan iş zenginleştirmeleri faaliyetlerinin getirmiş olduğu değişime karşı direndiklerini tespit etmişlerdir. Elias (2009) da çalışanların gelişme ihtiyacının gücü ile değişime ilişkin tutumlarının arasında pozitif ilişki olduğunu ve gelişme ihtiyacının gücü yüksek olan bireylerin değişime ilişkin olumlu tutumlar geliştirdiklerini belirlemiştir. Benzer şekilde gelişme ihtiyacının gücü yüksek olan çalışanların gelişime ilişkin olumlu tutumlar sahip olması beklenmektedir.

Hipotez 7: Gelişme ihtiyacı gücü ile değişime ilişkin tutumlar arasında anlamlı ve pozitif bir ilişki vardır. 


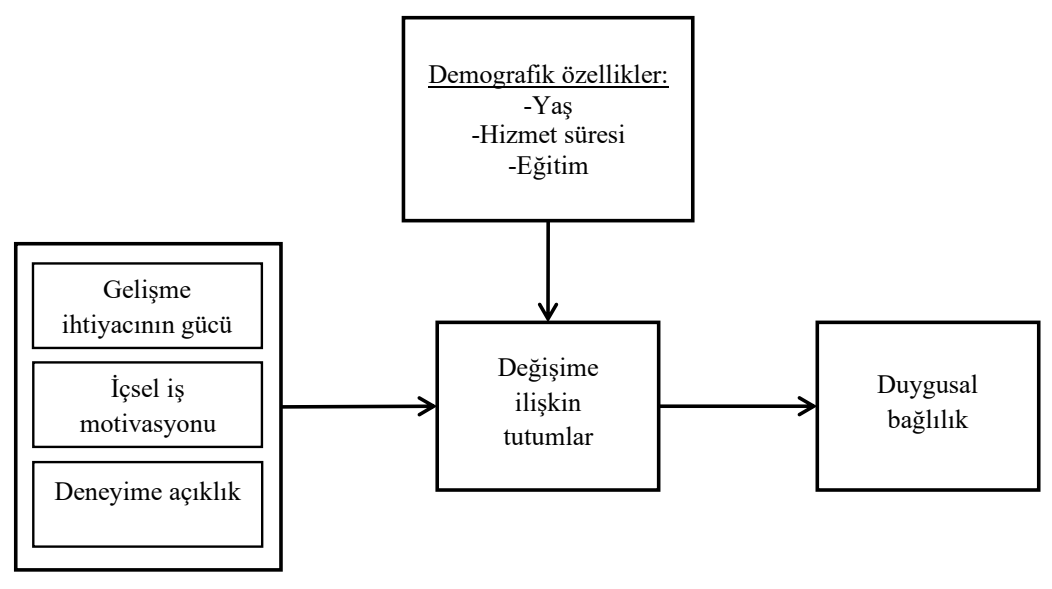

Şekil 1. Araştırmanın Modeli

Gelişme ihtiyacının gücü yüksek olan çalışanlar, işlerinin onlara gelişim firsatları sunması halinde işlerine ve dolayısıyla örgütlerine daha fazla duygusal bağlılık duymaktadırlar (Elias, 2009). Diğer yandan gelişme ihtiyacının gücü düşük olan çalışanlar, örgütsel değişimin getirdiği yenilikleri ve gerektirdiği ilave çabayı kendileri için ilave bir yük ve tehdit olarak algılayacaklarından dolayı (Houkes ve ark., 2001) değişime karşı olumsuz tutumlar geliştirmek suretiyle çalışanların örgütlerine yönelik hissettikleri duygusal bağlılık düzeyleri düşebilecektir. Wanberg ve Banas (2000), bireysel özelliklerin örgütsel değişime açık olmayı etkilediğini, örgütsel değişime açık olmanın ise iş tatminini artırdığını ve işten ayrılma niyetini azalttığını tespit etmiştir. Elias (2009) gelişme ihtiyacının gücü ile duygusal bağlılık arasındaki ilişkide değişime ilişkin tutumların aracılık rolü oynadığını belirlemiştir. Bu görgül kanıtlardan yola çıkarak şu hipotez geliştirilmiştir:

Hipotez 8: Gelişme ihtiyacının gücü ile duygusal bağlılık arasındaki ilişkide değişime ilişkin tutumların aracılık rolü vardır.

\section{Yöntem}

\section{Örneklem}

Bu çalışma doğası itibarıyla sürekli değişim içerisinde olan askeri bir kurumda yürütülmüştür. Türk Silahlı Kuvvetleri'nin (TSK) sürekli bir değişim ve dönüşüm içerisinde olduğunu ifade eden bilimsel çalışmalar mevcuttur. Örneğin, Moskos, Williams ve Segal (2000), Soğuk Savaş döneminden sonra batı ordularının liderlik tarzları, örgütsel yapıları, işe alım süreçleri vb. konularda kayda değer değişimler yaşadıklarını ifade etmektedir. Moskos ve arkadaşlarının (2000) post-modern askeri çerçevesini TSK'ya uygulayan Satana (2008), Türk Silahlı Kuvvetleri'nin tehdit algılaması, görev tanımı, kuvvet yapısı, halkla ilişkiler, sivil çalışanlar, kadınların askeri yapı içindeki rolü ve benzeri konularda bir değişim ve dönüşüm içerisinde olduğu yargısına ulaşmıştır. Satana'ya (2008) göre TSK, modern dönemden post-modern döneme geçişi, zamanında ve yerinde uygulamayı başarmaktadır. Varoğlu ve Bıçaksız (2005) da TSK'nın personel bakımından profesyonelleşme çabaları içinde olduğunu ileri sürmektedir. Diğer yandan, 2003 y1lında North Atlantic Treaty Organization (NATO) bünyesindeki değişim ve dönüşümü yönetmeye odaklanılması maksadıyla Müttefik Dönüşüm Komutanlığı'nın kurulmasiyla birlikte (Allied Command Transformation, 2018) TSK'nın NATO bünyesindeki değişim gayretlerinden etkilendiği ve örgütsel yapı, insan kaynakları, modernizasyon çalışmaları vb. konularda sürekli bir değişim ve dönüşüm içerisinde olduğu ifade edilebilir.

$\mathrm{Bu}$ çalışma Kara Kuvvetleri Komutanlığı'nda (KKK) yapılmıştır. Araştırma verisinin toplandığı zaman periyodunda araştırmanın yapıldığı kurumda, TSK-2033 Yeniden Yapılandırma Direktifi ile birtakım yeniden yapılanma ve dönüşüm faaliyetleri başlatılmış hatta bu konuda kurumun öncülük ettiği "Askeri Organizasyonlarda Değişim ve Dönüşümün Yönetimi Sempozyumu” temasıyla 16-17 Haziran 2016 tarihlerinde bilimsel bir etkinlik yapılmıştır (KHO, 2016). Araştırmanın yürütüldüğü yıllarda KKK'da değişim ve dönüşüm kapsamında; Kuvvet yapısının etkinleştirilmesine yönelik projeler (merkezi yeteneklerin oluşturulması, hava savunma yeteneğinin artırılması, vb.), karargâhların etkinliğinin artırılmasına yönelik projeler, sınır fiziki güvenlik sisteminin etkinliğinin artırılmasına yönelik projeler, kışlaların yeniden yapılandırılması projeleri ve k@plan (kariyer 
planlama) projesi gibi birçok yeniden yapılanma girişimlerinden bahsedilebilir (Öztürk, 2016).

$\mathrm{Bu}$ çalışmanın evrenini, KKK'da görev yapmakta olan subaylar oluşturmaktadır. Araştırmanın örneklemi, kolayda örnekleme tekniği (Gürbüz ve Şahin, 2018) ile seçilen 783 subay katılımcıdan oluşmaktadır. Katılımcıların 13'ü kadın (\%1.7), 770'i erkek (\%98.3); 101'i bekar (\%12.9), 682'si evli (\%87.1); 463'ü lisans mezunu (\%59.1), 290'1 yüksek lisans mezunu (\%37.1), 30'u doktora mezunudur (\%3.8). Katılımciların yaş ortalaması 37.3 yaş $(S=12.7)$ ve hizmet süresi ortalaması $14.5(S=7.9)$ yıldır.

\section{Veri Toplama Araçlart ve Veri Toplama Süreci}

Veri toplama tekniği olarak anket tekniği kullanılmıştır. Anketler, katılımcılara KKK birliklerini kapsayan bir intranet ağı üzerinden, çalışma ortamında elektronik olarak sunulmuştur. Anket, 2016 y1lının Şubat ayında 15 gün boyunca intranet ağında aktif halde tutularak araştırmaya katılmak isteyenlerin anketi diledikleri vakitte doldurabilmelerine olanak sağlanmıştır. Verilerin toplanmasında katılımcıların gönüllü olarak katılımı esas alınmıştır. Araştırmada kullanılan veri toplama araçlarının tamamı 5'li Likert tipindedir. Katılımcılardan ölçeklerde bulunan her bir maddeye ne ölçüde katıldıklarını 5 basamaklı Likert tipi ölçeklere göre (örn., 1 = Kesinlikle katılmıyorum, 5 = Kesinlikle katıliyorum) değerlendirmeleri istenmiştir. Ölçeklerden alınan yüksek puanlar katılımcıların ilgili değişkene ilişkin puanlarının yüksek düzeyde olduğunu göstermektedir.

Değişime İlişkin Tutumlar. Katılımcıların değişime yönelik tutumları Dunham, Grube, Gardner, Cummings ve Pierce (1989) tarafindan geliştirilen 18 maddelik değişime yönelik tutumlar ölçeği (örnek madde: Çalıştığım kurumun sürekli bir değişim içinde olmasinı isterim) kullanılarak ölçülmüştür. Söz konusu ölçek, alanyazındaki ölçek uyarlama prosedürleri (Bayık ve Gürbüz, 2016; Brislin, Lonner ve Thorndike, 1973, Ægisdóttir, Gerstein ve Çınarbaş, 2008) dikkate alınarak tarafımızdan Türkçeye uyarlanmıştır. Bu kapsamda; öncelikle ölçekler İngilizceden Türkçeye çevrilmiş, sonrasında ölçekler İngilizceye geri çevrilmiş ve itilaflı maddeler için uzman görüşü alınmıştır. Tüm çeviri aşamalarında, Türkçe ve İngilizceye hâkim en az iki kişilik komisyon kullanılmıştır. Ölçeğin yapısal geçerliliğini doğrulamak amaciyla birinci düzey tek faktörlü doğrulayıcı faktör analizi yapılmıştır (Gürbüz ve Şahin, 2018). Yapılan analiz neticesinde, ölçeğin tek faktörlü yapısı ilk aşamada doğrulanamamıştır. Düzeltme indeks değerleri, faktör yükleri ve standardize artık kovaryans değerleri dikkate alınarak yedi madde analizden çıkarılmış ve analiz tekrarlanmıştır. Tekrarlanan doğrulayıcı faktör analizi sonucunda elde edilen uyum iyiliği değerlerinin $[\chi 2(\mathrm{~N}$ $=783)=188.534, p>.05, \chi 2 / s d=4.39$, RMSEA $=.06$,
$\mathrm{CFI}=.97, \mathrm{SRMR}=.05]$ yazında kabul edilen seviyelerde olduğu tespit edilmiştir (Gürbüz ve Şahin, 2018). Ölçeğin iç tutarlılık katsayısı .91 olarak hesaplanmıştır. Ölçek maddeleri Ek-1'de sunulmuştur.

Duygusal Bağllık. Çalışanların duygusal bağlık düzeyleri; Meyer, Allen ve Smith (1993) tarafindan geliştirilen ve Türkçe uyarlaması Wasti (2003) tarafindan yapılan örgütsel bağlılık ölçeğinin duygusal bağllılık alt boyutundaki altı madde ile (örnek madde: Meslek hayatımın kalan kısmını halen çallş̧tı̆ıı kurumda geçirmek beni çok mutlu eder) ölçülmüsştür. Altı maddeden oluşan duygusal bağlllık ölçeğinin birinci düzey tek faktörlü yapisı doğrulayıcı faktör analizi ile test edilmiştir. Analiz sonucunda elde edilen uyum iyiliği değerlerinin $[\chi 2(\mathrm{~N}=$ $783)=60.125, p>.05, \chi 2 / s d=3.20$, RMSEA $=.07$, CFI $=.98, \mathrm{SRMR}=.05]$ yazında kabul edilen seviyelerde olduğu tespit edilmiştir (Gürbüz ve Şahin, 2018). Ölçeğin iç tutarlılık katsayısı .88 olarak hesaplanmıştır.

İçsel İş Motivasyonu. İçsel iş motivasyonunu ölçmek amaciyla Hackman ve Oldham (1974) tarafindan geliştirilen ve bu çalışma kapsamında Türkçeye uyarlaması yapılan dört maddeli içsel iş motivasyonu ölçeği (örnek madde: Bu işi iyi yaptığım zaman büyük bir kişsisel tatmin hissi duyarım) kullanılmıștır. Dört maddeden oluşan içsel iş motivasyonu ölçeğinin birinci düzey tek faktörlü yapısı, doğrulayıcı faktör analizi ile test edilmiştir. Analiz sonucunda elde edilen uyum iyiliği değerleri$\operatorname{nin}\left[\chi^{2}(\mathrm{~N}=783)=31.125, p>.05 ; \chi^{2} / s d=2.25\right.$, RM$\mathrm{SEA}=.06, \mathrm{CFI}=.99, \mathrm{SRMR}=.05]$ yazında kabul edilen seviyelerde olduğu tespit edilmiştir (Gürbüz ve Şahin, 2018). Ölçeğin iç tutarlılık katsayısı .86 olarak hesaplanmıştır. Ölçek maddeleri Ek-1'de sunulmuştur.

Deneyime Açıklık. Beş Faktör Kişilik Özelliklerinin bir boyutu olan deneyime açıklık; Benet-Martinez ve John (1998) tarafindan geliştirilen ve Sümer, Lajunen ve Özkan (2005) tarafından Türkçeye uyarlanan Beş Faktör Kişilik Özellikleri envanterinin deneyime açıklık boyutundaki 10 madde (örnek madde: Orijinal, yeni görüssler ortaya koyan bir özelliğe sahibim) kullanılarak ölçülmüştür. On maddeden oluşan ölçeğin birinci düzey tek faktörlü yapısı, doğrulayıcı faktör analizi ile test edilmiştir. Yapılan analiz neticesinde, ölçeğin tek faktörlü yapısı ilk aşamada doğrulanamamıştır. Düzeltme indeks değerleri, faktör yükleri ve standardize artık kovaryans değerleri dikkate alınarak üç madde analizden çıkarılmış ve analiz tekrarlanmıştır. Analiz sonucunda elde edilen uyum iyiliği değerlerinin $[\chi 2(\mathrm{~N}=783)=99.792, p>$ $.05, \chi^{2} / s d=4.49$, RMSEA $=.07, \mathrm{CFI}=.99$, SRMR $=$ .05] yazında kabul edilen seviyelerde olduğu tespit edilmiştir (Gürbüz ve Şahin, 2018). Ölçeğin iç tutarlılık katsayısı .81 olarak hesaplanmıştır.

Gelişme Íhtiyacının Gücü. Gelişme ihtiyacının gücünü ölçmek amacıyla Hackman ve Oldham (1980) 
tarafından geliştirilen ve bu çalışma kapsamında Türkçeye uyarlaması yapılan altı maddeli gelişme ihtiyac1nın gücü ölçeği (örnek madde: Yaptığım işin yeni şeyler ögrenme firsatı sağlamasını isterim) kullanılmıştır. Altı maddeden oluşan ölçeğin birinci düzey tek faktörlü yapısı, doğrulayıcı faktör analizi ile test edilmiştir. Analiz sonucunda elde edilen uyum iyiliği değerlerinin $[\chi 2(\mathrm{~N}$ $=783)=26.940, p>.05, \chi 2 / s d=3.25, \mathrm{RMSEA}=.05$, $\mathrm{CFI}=.99$, GFI $=.99]$ yazında kabul edilen seviyelerde olduğu tespit edilmiştir (Gürbüz ve Şahin, 2018). Ölçeğin iç tutarlılık katsayısı .89 olarak hesaplanmıştır. Ölçek maddeleri Ek-1'de sunulmuştur.

\section{İslem ve Analizler}

Toplanan veriler IBM SPSS 22 ve IBM AMOS paket programları ile analiz edilmiştir. Kullanılan ölçeklerin güvenirliklerini belirlemek için Cronbach alpha değerleri hesaplanmış, geçerliklerini tespit etmek amacıyla doğrulayıcı faktör analizi yapılmıştır. Hipotezlerin test edilmesinde ise korelasyon analizi, ANOVA ve yap1sal eşitlik modellemesi (YEM) kullanılmıștır. YEM'de maksimum olabilirlik yöntemi ile analizler yapılmıştır. YEM ile öncelikle önerilen tam aracılı model test edilmiş, bu modelin veriyle doğrulanmaması durumunda, modelde anlamsız bulunan yollar modelden çıkarılarak tadil edilmiș nihai model oluşturulmuștur. Söz konusu iki modelin, $\Delta X^{2}$ farklılık testleri (Jöreskog, 1993) birbirleri ile kıyaslanmış ve en iyi uyum iyiliği değerlerine ulaşılan modele göre araştırmanın hipotezleri değerlendirilmiştir.
Son yıllarda bazı araştırmacılar, aracılık modellerinin testinde Baron ve Kenny (1986) yönteminin arac1lık testleri için güçlü bir yöntem olmadığını öne sürerek bu geleneksel yöntem yerine bootstrap tekniğine dayanan ve daha güvenilir sonuçlar veren çağdaş yaklaşımın kullanılması gerektiğini (Darlington ve Hayes, 2017; Gürbüz, 2019; Hayes, 2018; Hayes ve Rockwood, 2017; Rucker, Preacher, Tormala ve Petty, 2011), bootstrap yönteminin Baron ve Kenny'nin (1986) geleneksel yönteminden (Preacher, Rucker, ve Hayes, 2007) ve Sobel Testinden (Zhao, Lynch ve Chen, 2010) daha güvenilir sonuçlar verdiğini öne sürmüşlerdir. Çalışmamızda modern yaklaşım tercih edilerek Baron ve Kenny (1986) adımları ile Sobel Testi (Sobel, 1982) uygulanmamış, bootstrap neticesinde elde edilen güven aralığı değerleri doğrultusunda dolaylı etki değerleri raporlanmıștır.

\section{Bulgular}

Araştırmanın değişkenlerine ait ortalama, standart sapma, korelasyon ve güvenirlik değerleri Tablo-1'de sunulmuştur. Katılımcıların duygusal bağlılık (Ort. = $4.19, S=.77)$, değişime ilişkin tutumlar $($ Ort. $=4.34, S=$ .50 ), içsel iş motivasyonu (Ort. $=4.41, S=.66$ ), deneyime açılık (Ort. $=4.07, S=.50)$ ve gelişme ihtiyacının gücü (Ort. $=4.39, S=.52)$ değișkenlerine ait ortalamalarının 4.07 ve üzerinde olduğu görülmektedir. Buradan hareketle katılımcıların değişime ilişkin tutumları ile duygusal bağlılıklarının ortalamalarının yüksek düzeyde olduğu ifade edilebilir. Benzer şekilde katılımcıların iç-

Tablo 1. Araştırmanın Değişkenlerine Ait Ortalama, Standart Sapma, Korelasyon ve Güvenirlik Değerleri

\begin{tabular}{|c|c|c|c|c|c|c|c|c|c|c|}
\hline Değişkenler & Ort. & $S$ & 1 & 2 & 3 & 4 & 5 & 6 & 7 & 8 \\
\hline 1. Yaş & 37.30 & 12.71 & - & & & & & & & \\
\hline 2. Hizmet süresi & 14.47 & 7.95 & $.55^{* *}$ & - & & & & & & \\
\hline 3. Eğitim düzeyi & 1.45 & .57 & $.21 * *$ & $.38 * *$ & - & & & & & \\
\hline 4. Duygusal bağlılık & 4.19 & .77 & -.03 & -.02 & -.07 & $(.88)$ & & & & \\
\hline 5. Değişime ilişkin tutumlar & 4.34 & .50 & -.07 & $-.18 * *$ & -.02 & $.23 * *$ & $(.91)$ & & & \\
\hline 6. İçsel iş motivasyonu & 4.41 & .66 & -.06 & .00 & .02 & $.43^{* *}$ & $.35^{* *}$ & $(.86)$ & & \\
\hline 7. Deneyime açıklık & 4.07 & .50 & $-.08^{*}$ & $-.16 * *$ & .00 & $.23 * *$ & $.62 * *$ & $.32 * *$ & $(.81)$ & \\
\hline 8. Gelișme ihtiyacının gücü & 4.39 & .52 & -.06 & $-.14 * *$ & .02 & $.24 * *$ & $.56 * *$ & $.37 * *$ & $.67 * *$ & $(.89)$ \\
\hline
\end{tabular}

Not 1. ${ }^{*} p<.05, *^{*} p<.01$, Parantez içindeki değerler Cronbach alfa güvenirlik katsayısıdır.

Not 2. Eğitim düzeyi: 1 = lisans, 2 = yüksek lisans, 3 = doktora olarak kodlanmıştır. 
Tablo 2. Eğitim Durumuna Göre Çalışanların Değişime İlişkin Tutumlarına Yönelik İstatistikler ve Tek Faktörlü ANOVA Sonuçları

\begin{tabular}{lccccc}
\hline & $N$ & Ort. & $S$ & $F$ & $p$ \\
\hline Lisans & 463 & 4.36 & .50 & 4.705 & .009 \\
Yüksek lisans & 290 & 4.28 & .51 & .41 \\
Doktora & 30 & 4.53 & .50 & \\
Toplam & 783 & 4.34 & & \\
\hline
\end{tabular}

sel iş motivasyonu, deneyime açıklık ve gelişme ihtiyacının gücü değerlerinin de 4.07 ile 4.41 arasında olduğu görülmektedir.

Çalışanların yaşı ile araştırmanın bağımlı değişkenleri arasından sadece deneyime açıklık arasında $(r=$ $-.08, p<.05$ ) anlamlı ve negatif bir ilişki olduğu; yaşı daha yükssek olan çalışanların deneyime açıklık kişilik özelliği değerlerinin daha düşük düzeyde olduğu belirlenmiştir. Yaş ile değişime ilişkin tutumlar arasında korelasyonel ilişkinin negatif yönde ve anlamlı olmaması nedeniyle $H 1$ a hipotezi destek bulmamıştır. Hizmet süresi ile değişime ilişkin tutumlar $(r=-.18, p<.01)$, deneyime açıklık $(r=-.16, p<.01)$ ve gelişme ihtiyacının gücü $(r$ $=-.14, p<.01)$ arasındaki korelasyonel ilişkilerin zayıf, anlamlı ve negatif yönde olduğu tespit edilmiştir. Hizmet süresi arttıkça çalışanların değişime ilişkin tutumları ile gelişme ihtiyacının gücünün düşüş gösterdiği ve hizmet süresi fazla olan çalışanların deneyime açıklık değerlerinin daha düşük düzeyde olduğu ortaya çıkmıştır. $\mathrm{Bu}$ nedenle hizmet süresi ile değişime ilişkin tutumlar arasında negatif ve anlamlı bir ilişki olduğunu öneren $H 1 b$ hipotezi desteklenmiştir.

Çalışanların eğitim düzeylerine göre değişime ilişkin tutumları arasında bir farklılık olup olmadığını test etmek için tek faktörlü varyans analizi (ANOVA) yapılmıştır. Katılımcı sayısının üç bağımsız değişken gurubu (lisans, yüksek lisans ve doktora mezunu) arasında eşit olmaması nedeniyle ANOVA testinden önce ANOVA testi için önkoşul olan varyansın homojen olduğu varsayımı Levene testi ile test edilmiştir. Levene testi sonucunun istatistiksel olarak anlamlı olmaması $\left(F_{(2,780)}=\right.$ $2.056, p=.129)$ nedeniyle üç bağımsız değişken gurubu (lisans, yüksek lisans ve doktora mezunu) içerisinde varyansın homojen olduğu sonucuna ulaşılarak ANOVA testine geçilmiştir. ANOVA sonuçlarına göre (bkz. Tablo-2) çalışanların eğitim düzeyleri ve değişime ilişkin tutumları arasında anlamlı bir ilişki vardır $\left(F_{(2,780)}=4.705\right.$, $p<.01)$. Başka bir ifade ile çalışanların değişime ilişkin tutumları eğitim düzeylerine göre farklılık göstermekte- dir. Tukey testi sonuçlarına göre lisans (Ort. $=4.36, S=$ $.50)$ ve yüksek lisans (Ort. $=4.28, S=.50)$ mezunlarının değişime ilişkin tutumları arasında anlamlı bir farklılık yoktur. Ancak doktora mezunlarının (Ort. $=4.53, S=$ .50) değişime ilişskin tutumları ile lisans ve yüksek lisans mezunlarının değişime ilişkin tutumları arasında anlamlı bir farkl1lık olduğu görülmüştür. Bu durum, eğitim düzeyi yüksek katılımcıların değişime daha açık olduklarını göstermektedir. Bu nedenle Hlc hipotezi desteklenmiştir.

Değişime ilişkin tutumlar ile araştırmanın demografik değişkenleri haricindeki diğer değişkenler arasındaki ilişkiler YEM ile analiz edilmiştir. Demografik değişkenlerin YEM analizine dahil edilmemesinin temel nedeni, YEM modelini basit tutmak ve hipotez testlerinde kararsızlık ikilemine düşmemektir (Kline, 2016). Örneğin; ANOVA testinde desteklenen hipotezin YEM'de değişkenler arasındaki etkileşimsel etkilerden dolayı etkisi anlamlı bulunamayabilir. Bu durumda hipotezin desteklenip desteklenmediği kararında ikilem yaşanacaktır.

Söz konusu değişkenler arasındaki ilişkiler hakkında bir fikir vermesi bakımından aralarındaki korelasyonel ilişkiler incelenmiştir. Değişime ilişkin tutumlar ile araştırmanın diğer değişkenleri arasındaki korelasyonel ilișkiler incelendiğinde (bkz. Tablo 1) değișime ilişkin tutumlar ile duygusal bağlilık $(r=.23, p<.01)$ arasında zayıf, anlamlı ve negatif bir ilişkinin olduğu; değişime ilişkin tutumlar ile içsel iş motivasyonu $(r=.35, p<.01)$, deneyime açıklık $(r=.62, p<.01)$ ve gelişme ihtiyacının gücü $(r=.56, p<.01)$ arasında ise orta düzeyde, anlamlı ve pozitif ilişkiler olduğu tespit edilmiştir. Duygusal bağlılık ile içsel iş motivasyonu $(r=.43, p<.01)$ arasındaki ilişkinin orta düzeyde anlamlı ve pozitif yönde; duygusal bağlılık ile deneyime açıklık $(r=.23, p<.01)$ ve gelişme ihtiyacının gücü $(r=.24, p<.01)$ arasındaki ilişkilerin ise zayıf, anlamlı ve pozitif yönde olduğu görülmüştür.

YEM analizi kapsamında araştırmanın değişkenleri arasındaki ilişkiler öncelikle tam aracılık modeline göre test edilmiştir. Yapılan analizler neticesinde tam aracılık 


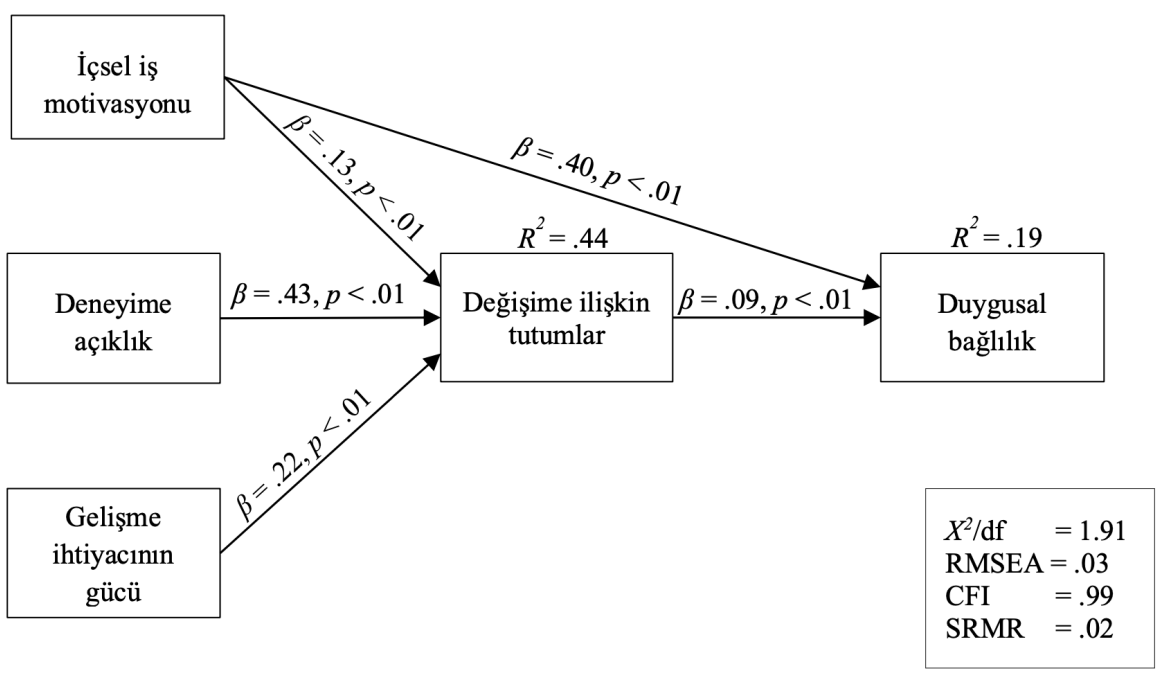

İçsel iş motivasyonu: Doğrudan etki, $\beta=.40, p<.01$; Dolaylı etki, .011, \%95 GA [.003, .024]

Deneyime açıklık: Doğrudan etki, $\beta=.05, p=.14$; Dolaylı etki, .037, \%95 GA [.008, .069]

Gelişme ihtiyacının gücü: Doğrudan etki, $\beta=.04, p=.30$; Dolaylı etki, .019, \%95 GA [.005, .040]

Not. Standardize edilmiş beta katsayı $(\beta)$ değerleri raporlanmıştır. $\mathrm{R}^{2}$ değerleri, açıklanan varyansı göstermektedir. RMSEA: Root Mean Square Error of Approximation; CFI: Comparative Fit Index; SRMR: Standardized Root Mean Square Residual.

Şekil 2. Tadil Edilmiş Yapısal Model, Standart Yol Katsayıları, Açıklanan Varyanslar, Doğrudan Etki Değerleri, Dolaylı Etki Değerleri ve Uyum İyiliği Değerleri

modelinin uyum iyiliği değerlerinin yazında kabul gören değerlere (Gürbüz ve Şahin, 2018) uygun olmadığı tespit edilmiştir $\left[X^{2}(3, \mathrm{~N}=783)=128.356, p>.01, X^{2} / \mathrm{df}\right.$ $=42.785, \mathrm{RMSEA}=.23, \mathrm{CFI}=.89, \mathrm{SRMR}=.17] \mathrm{Bu}$ durumda, modelde anlamsiz bulunan yollar modelden çıkarılarak tadil edilmiş nihai bir model oluşturulmuştur. Anlamsız yolların çıkarıldığı tadil edilmiş modele (Şekil 2) ilişkin uyum iyiliği değerlerinin yazında kabul gören değerlere uygun olduğu $\left[X^{2}(2, \mathrm{~N}=783)=3.828, p>.01\right.$, $\left.X^{2} / \mathrm{sd}=1.91, \mathrm{RMSEA}=.03, \mathrm{CFI}=.99, \mathrm{SRMR}=.02\right]$ tespit edilmiştir. Yapılan $\Delta X^{2}$ farklılık testi neticesinde iki model arasındaki farklılığın anlamlı düzeyde olduğu $\left(\Delta X^{2}=124.528, p<.001\right)$ belirlenmiştir.

Şekil 2'de tadil edilmiş yapısal modele ilişkin standart yol katsayıları sunulmuştur. Değişime ilişkin tutumlardan duygusal bağl1lık değişkenine giden yol katsayısı anlamlı $(\beta=.09, p<.05)$ olduğundan dolay1 $H 2$ desteklenmiştir. Ancak bu etkinin çok yüksek olmadığ1 görülmektedir. Alanyazında benzer bir çalışmada söz konusu etkinin görece daha yüksek $(\beta=.19, p<.01)$ olduğu bulunmuştur (Elias, 2009). Dolayısıyla değişime ilişkin tutumların, duygusal bağlılığa etkisi bu çalışmada nispeten daha düşüktür. İçsel iş motivasyonu $(\beta=.13, \mathrm{p}$
$<.05)$, deneyime açıklık $(\beta=.43, p<.05)$ ve gelişme ihtiyacının gücü $(\beta=.22, p<.05)$ değişkenlerinden değişime ilişkin tutumlar değişkenine giden yol katsayıları da anlamlı bulunmuştur. Bu nedenle $H 3, H 5$ ve $H 7$ desteklenmiştir.

Tadil edilmiş yapısal model incelendiğinde değişime ilişkin tutumların içsel iş motivasyonu, deneyime açıklık ve gelişme ihtiyacının gücü ile duygusal bağlılık arasında aracılık rolü bulunduğu belirlenmiştir (bkz. Şekil 2). Aracilık modelleri, dolaylı etkilere ait bootstrap sonuçları ve doğrudan etkiler daha ayrıntılı incelendiğinde içsel iş motivasyonunun hem doğrudan $(\beta=.40$, $p<.01)$ hem de değişime ilişkin tutumlar vasıtasıyla (Dolayl1 etki $=.011, \% 95$ GA $[.003, .024]$ ) duygusal bağlılık üzerinde etkili olduğu görülmektedir. Deneyime açıklık ve gelişme ihtiyacının gücünün ise duygusal bağlılık üzerinde doğrudan etkilerinin anlamlı olmadığ 1 (sırasıyla $\beta=.05, p=.14$ ve $\beta=.04, p=.30$ ); buna karşın değişime ilişkin tutumlar vasıtasıyla duygusal bağlılık değișkenini yordadıkları tespit edilmiștir (Dolaylı etki = $.037, \% 95$ GA $[.008, .069]$ ve Dolaylı etki $=.019, \% 95$ GA $[.005, .040]$, sirasiyla). Bu bulgular doğrultusunda H4, H6 ve $H 8$ desteklenmiştir. 


\section{Tartıșma}

Canlı ve çevresiyle etkileşim içerisinde birer sistem olan örgütler sürekli bir değişim içerisindedir. Her ne kadar örgüt kültürü ve çekim-seçim-yıpranma (Schneider, 1987) süreci, çalışanları benzer niteliklere sahip kılma yönünde etkili olsa da çalışanların bazı özellikleri onlar arasında belirgin farklılıklar oluşmasına neden olmaktadır. Değişim yönetimi açısından bakıldığında çalışanlar arasındaki farklılıklar çalışanların değişime ilişkin tutumlarına da yansımaktadır. Bazı çalışanlar değişimi kendileri için bir öğrenme ve gelişim firsatı olarak görmekte, kişilik özellikleri ile uyumlu olduğunu hissettiği için değişime kolaylıkla uyum sağlayabilmekte ve örgütsel değişimi destekleyici bir tutum içerisine girmektedirler. Bazı çalışanlar ise değişimi ilave çaba gösterilmesi gereken bir zorunluluk olarak görmekte ve değişime karş1 olumsuz tutumlar sergileme ve değişime karşı direnme davranışı içerisine girmektedirler.

Örgütsel değişim gayretlerinin başarılı veya başarısız olması çalıșanların değişime ilişkin tutumlarının olumlu ya da olumsuz olmasına bağlıdır (Lines, 2005). Eğer çalışanlar örgütsel değişime ilişkin olumlu tutumlara sahip ise çalışanlar örgütsel değişimi destekleyeceklerinden dolayı örgütsel değişim gayretlerinin başarılı olma ihtimali artmaktadır. Eğer çalışanların örgütsel değişime ilişkin olumsuz tutumları var ise örgütsel değişim gayretlerinin başarılı olması için yöneticiler çalışanların bu olumsuz tutumlarını ortadan kaldırmalı ve örgütsel değişim gayretlerinde çalışanların desteğini kazanmalıdirlar (Antoni, 2004).

Bu çalışmada, örgütsel değişime ilişkin tutumların öncülleri olarak demografik özellikler ile birlikte içsel iş motivasyonu, deneyime açıklık ve gelişme ihtiyacının gücü ele alınmış, değişime ilişkin tutumların söz konusu değişkenler ile duygusal bağlılık arasında aracılık rolü olup olmadığı incelenmiştir. Elde edilen bulgular doğrultusunda çalışanların yaşının değişime ilişkin tutumlar1 üzerinde herhangi bir etkisinin olmadığı; çalışanların hizmet süresi ve eğitim düzeyinin ise değişime ilişkin tutumlar ile ilişkili olduğu tespit edilmiştir. Çalışanların hizmet süreleri ile değişime ilişkin tutumlarının negatif yönde ilişkili olduğu; hizmet süresi uzun olan çalışanların, hizmet süresi kısa olan çalışanlara göre değişime ilişkin daha olumsuz tutumlarının olduğu belirlenmiştir. Lisans ve yüksek lisans mezunları olan çalışanlar arasında değişime ilişkin tutumları açısından bir fark yokken doktora mezunu olan çalışanların değişime ilişkin tutumlarının lisans ve yüksek lisans mezunu olan çalışanlardan farklılaştı̆̆ ve daha olumlu olduğu ortaya çıkmıştır. Yapılan YEM analizi neticesinde içsel iş motivasyonu, deneyime açıklık ve gelişme ihtiyacının gücünün değişime ilişkin tutumların öncülü olduğu; içsel iş moti- vasyonu, deneyime açıklık ve gelişme ihtiyacının gücü ile değişime ilişkin tutumlar arasında pozitif bir ilişki bulunduğu ve söz konusu özellikleri yüksek düzeyde olan çalışanların değişime ilişkin olumlu tutumlarının olduğu tespit edilmiştir. Ayrıca değişime ilişkin tutumların; içsel iş motivasyonu, deneyime açıklık ve gelişme ihtiyacının gücü ile duygusal bağlılık arasındaki ilişkide aracılık rolü oynadığ 1 bulgusuna ulaşılmıştır.

İçsel iş motivasyonun değişime ilişkin tutumların öncülü olduğu ve pozitif yönde etki yarattığına ilişkin bulgunun önceki çalışmaların bulguları ile örtüştüğü görülmektedir (Amabile ve ark., 1994; Elias, 2009; Houkes ve ark., 2001; Ryan ve Deci, 2000). İçsel iş motivasyonu yüksek olan çalışanların, kendilerinin yeteneklerini geliştiren bireysel hedefler belirleyerek kişisel gelişimlerine katkıda bulunan işlerden daha çok hoşlanmaları nedeniyle (Amabile ve ark., 1994) bu özelliği yüksek düzeyde olan çalışanların değişime ilişkin olumlu tutumlar geliştirdikleri ifade edilebilir. Çalışanların değiş̧ime ilişkin tutumlarının, içsel iş motivasyonları ile duygusal bağlılıkları arasındaki ilişkide aracılık rolü oynaması nedeniyle çalışanların içsel iş motivasyonunun yüksek düzeyde olması, onların duygusal bağlılık düzeylerine hem doğrudan ve hem de değişime ilişkin tutumlarını pozitif yönde etkilemek suretiyle dolaylı olarak etki etmekte ve duygusal bağlılık düzeylerini artırmaktadır. İçsel iş motivasyonunun duygusal bağlılık ile hem doğrudan hem de dolaylı olarak pozitif ilişkisinin bulunması daha önceki çalışmaların bulgularını destekler niteliktedir (Eby ve ark., 1999; Elias, 2009; Mathieu ve Zajac, 1990; Moon, 2000). Beş Faktör kişilik özelliklerinden deneyime açıklık kişilik özelliğinin zekâ, kavrayış, yaratıcılık, hayal gücü, kültürlü olma, hoşgörü ve meraklılık gibi özellikler ile ilişkilendirilmesi nedeniyle (Barrick ve Mount, 1991; Goldberg, 1992) deneyime açıklık düzeyi ile değişime ilişkin tutumlar arasında pozitif bir ilişkinin beklenen bir sonuç olduğu ve daha önceki çalışmaların bulgularını destekler nitelikte olduğu ifade edilebilir (Judge ve ark., 1999; LePine ve ark., 2000; Pulakos ve ark., 2000; Vakola ve ark., 2004). Gelişme ihtiyacının gücünün yüksek olmasının değişime ilişkin tutumları pozitif yönde etkilemesine ilişkin bulgu, çalışanların iş zenginleştirme gibi değişimlerin ortaya çıkardığı yenilikçi ortamlarda çalışabilmesi açısından gelişme ihtiyacının gücünün önemli olduğunu gösteren daha önceki çalışmaların bulguları ile örtüşmektedir (Elias, 2009; Fok ve ark., 2000; Hackman ve Oldham, 1980, Houkes ve ark., 2001; Loher ve ark., 1985). Ayrıca değişime ilişkin tutumların gelişme ihtiyacının gücü ile duygusal bağlılık arasında aracılık rolü oynaması çalışanların gelişme ihtiyacının gücünün yüksek olduğu zaman değişime ilişkin olumlu tutumlarının ve dolayısıyla duygusal bağlılık düzeylerinin arttığını göstermektedir. 
Bu çalışmanın ilgili alanyazına iki temel katkısının olduğu ifade edilebilir. İlk olarak örgütsel değişimi konu alan daha önceki araştırmalarda daha çok makro ve örgütsel düzeydeki faktörlerin ele alındığı (örn., Judge ve ark., 1999; Vakola ve ark., 2004), buna karşın çalışanların psikolojik süreçleri gibi mikro düzeydeki değişkenlerin göz ardı edildiği görülmektedir (Elias, 2009; Fedor, Caldwell ve Herold, 2006; Wanberg ve Banas, 2000). $\mathrm{Bu}$ çalışma kapsamında gelişme ihtiyacının gücü, içsel iş motivasyonları ve deneyime açıklık gibi psikolojik süreçler ile önemli bir tutum olan örgütsel bağlılık araştırmaya konu edilerek değişim ve dönüşüm konusunda ilgili alanyazındaki araştırmaların genişletilmesine katk1 bulunulmuştur. Araştırmanın ikinci önemli katkısı ise Türkçe alanyazına kazandırılan ölçeklerdir. Bu araştırmada, değişime ilişkin tutumlar ölçeği, içsel iş motivasyonu ölçeği ve gelişme ihtiyacının gücü ölçeği Türkçeye uyarlanmıştır. Bundan sonra benzer konuda yapılacak araştırmalarda söz konusu ölçekler araştırmacılar tarafindan kullanılabilecektir.

Araştırma bulgularından yola çıkarak uygulamacılara yönelik de birtakım öneriler getirilebilir. Değişime ilişkin tutumların yöneticiler açısından değişim gayretlerinin başarılı olma ihtimalini öngörmede kritik öneme sahip olduğu görülmektedir. Bireylerin değişime ilişkin olumsuz tutumlarının olduğu tespit edildiğinde, söz konusu bireylerin bu olumsuz tutumlardan arındırılması yöneticiler veya değişim ajanlarının görevidir (Antoni, 2004). Demografik özelliklerden hizmet süresinin, değişime ilişkin tutumlar üzerinde negatif yönde etkisi olduğu dikkate alındığında değişim gayretlerine ilişkin yapılan bilgilendirme, bilinçlendirme ve ikna etme gibi eğitici faaliyetlerde hizmet süresi uzun olan personele daha fazla ağırlık verilmesinin değişim gayretlerinin başarısına önemli derecede katkı sağlayacağı düşünülmektedir. Değişime ilişkin tutumların öncülü olarak içsel iş motivasyonu, deneyime açıklık ve değişim ihtiyacının gücünün pozitif etkileri ise çalışanlarda söz konusu özelliklerin yüksek düzeyde olmasının sürekli örgütsel değişim gayretleri içerisinde olan örgütler açısından ne derecede önemli olduğuna işaret etmektedir. Bu nedenle; personel temininde içsel iş motivasyonu, deneyime açıklık kişilik özelliği ve gelişme ihtiyacının gücü yüksek olan adayların belirlenerek işe alınmasının örgütsel değişim faaliyetlerine katkı sağlayacağı ve personelin değişime direnmek yerine değişimi sahipleneceği ve değişime katkı sağlayacağı değerlendirilmektedir. Söz konusu özellikleri düşük düzeyde olanların belirlenmesi suretiyle değişime ilişkin bilgilendirme, bilinçlendirme ve ikna etme gibi eğitici faaliyetlerde bu personele ağırlık verilmesinin değişim gayretlerine olumlu etki yaratacağ1 düşünülmektedir. Yine söz konusu özelliklere sahip olan personelin temin edilmesinin; sahip oldukları özellikle- ri itibarıyla değişime ilişkin olumlu tutumlar içerisinde olmalarını sağlamakla birlikte, bu olumlu tutumlarının onların duygusal bağlılıklarını artırıcı etki yaratacağı ifade edilebilir. Söz konusu nedenlerden dolayı deneyime açık olmayan, düşük içsel motivasyonu olan ve düşük düzeyde gelişme ihtiyacının gücü olan çalışanların belirlenerek değişim gayretleri esnasında bu çalışanları değişime hazırlamada onlara özel ilgi gösterilmesinin önem taşıdığı söylenebilir.

Çalışmanın verilerinin tek kaynaktan ve kesitsel olarak toplanmış olması, ortak yöntem varyansına neden olduğu için araştırmanın bulguları açısından bir kısıt oluşturmaktadır (Podsakoff, MacKenzie ve Podsakoff, 2012). Ayrıca, katılımcıların sosyal beğenirlik algısının etkisinde kalarak olumlu yanıtlar vermiş olması ihtimalinin de araştırma için bir kısıt oluşturduğu söylenebilir. Gelecek dönemde yapılacak olan çalışmalarda verilerin farklı kaynaklardan toplanmasının (örneğin personelin kişilik özelliklerine ilişkin veriler daha önce yapılmış kişilik testlerinden elde edilebilir) ve boylamsal bir araştırma tasarımı yapılmasının elde edilecek olan bulguların geçerliğini artıracağı değerlendirilmektedir. Sosyal beğenirlik algısına ilave olarak verilerin çalışmanın yapıldığ1 kurumun kendi internet sistemi üstünden toplanmış olması nedeniyle çalışanların kimliklerinin ortaya çıkabileceği yönünde bir endișelerinin olabileceği ve bu endişelerinin ölçek maddelerine verdikleri cevapları etkilemiş olabileceği düşünülebilir. Bununla birlikte anketin başlangıcında kişisel verilerin toplanmayacağının ifade edildiği, anketin çalışanların kendi hesapları üzerinden doldurulması gibi bir zorunluluğun bulunmadı $\breve{g}_{1}$ ve söz konusu internet sistemi üzerinden buna benzer birçok anket uygulandığı dikkate alındığında katılımcıların böyle bir endişesinin olma ihtimalinin azaldığ 1 ancak araştırmanın sonuçlarının geçerliği açısından bir k1sit oluşturduğu ifade edilebilir. Diğer yandan; değişime ilişkin tutumların öncülü olarak müdahale edilebilir ve değiştirilebilir nitelikte bireysel özelliklere odaklanılmasının uygulamacılar için daha yol gösterici nitelikte sonuçlar ortaya koyacağı düşünülmektedir. Son olarak bu araştırma değişim ve yeniden yapılanma faaliyetlerinin belirli bir düzeyde yaşandığı askeri kurumda yürütüldüğünden araştırma bulguları söz konusu kurum ile sınırlıdır. Araştırma bulguları şirket birleşmeleri, devralmaları gibi yeniden yapılanmanın ve örgütsel değişimin çok daha belirgin olduğu durumları deneyimleyen şirket ve kurumlara genellenememektedir.

Değişim ve dönüşüm gayretleri içerisinde olan örgütlerin makro düzeydeki (örgüt düzeyi) hususlar yanında mikro düzeydeki (birey düzeyi) hususları da dikkate alması örgütsel değişim gayretlerinin başarısına katk1 sağlayacaktır. Çalışanların değişime ilişkin tutumlarının olumlu olmasının veya olumlu hale getirilmesinin; 
onların değişimi destekleyici tutum ve davranışlar geliştirmelerine neden olacağı ve aynı zamanda değişim ve dönüşüm sürecinde onların duygusal bağlılıklarını daha da artıracağı değerlendirilmektedir.

\section{Kaynaklar}

Allen, N. J. ve Meyer, J. P. (1990). The measurement and antecedents of affective, continuance and normative commitment to the organization. Journal of Occupational Psychology, 63(1), 1-18. doi.org/10.1111/j.2044-8325.1990. tb00506.x.

Allied Command Transformation (2018). Who we are. (20 Ağustos 2018 tarihinde https://www.act.nato. int/who-we-are adresinden alınmıştır).

Amabile, T. M., Hill, K. G., Hennessey, B. A. ve Tighe, E. M. (1994). The Work Preference Inventory: Assessing intrinsic and extrinsic motivational orientations. Journal of Personality and Social PSychology, 66(5), 950-967. doi.org/10.1037/00223514.66.5.950.

Antoni, C. H. (2004). Research note: A motivational perspective on change processes and outcomes. European Journal of Work and Organizational Psychology, 13(2), 197-216. doi. org/10.1080/13594320444000065.

Armenakis, A. A., Harris, S. G. ve Mossholder, K. W. (1993). Creating readiness for organizational change. Human Relations, 46(6), 681-703. doi. org/10.1177/001872679304600601.

Baron, M. ve Kenny, D. A. (1986). The moderator-mediator variable distinction in social psychological research: Conceptual, strategic and statistical considerations. Journal of Personality and Social Psychology, 51(6), 1173-1182. doi.org/10.1037/00223514.51.6.1173

Barrick, M. R. ve Mount, M. K. (1991). The big five personality dimensions and job performance: A meta-analysis. Personnel Psychology, 44(1), 1-26. doi.org/10.1111/j.1744-6570.1991.tb00688.x

Bayık, M. E. ve Gürbüz, S. (2016). Ölçek uyarlamada metodoloji sorunu: Yönetim ve örgüt alanında uyarlanan ölçekler üzerinden bir araştırma. Işs ve Insan Dergisi, 3(1), 1-20. doi.org/10.18394/ iid. 15648

Beer, M. ve Nohria, N. (2000). Cracking the code of change. Harvard Business Review, 78(2), 13341 .

Benet-Martinez, V. ve John, O. P. (1998). Los Cinco Grandes across cultures and ethnic groups: Multitrait-multimethod analyses of the Big Five in Spanish and English. Journal of Personality and Social Psychology, 75(3), 729-750. doi. org/10.1037/0022-3514.75.3.729.

Bertalanffy, L. (1950). An outline of general system theory. British Journal for the Philosophy of Science, 1, 134-165. 
Bouckenooghe, D., Devos, G. ve Van den Broeck, H. (2009). Organizational change questionnaire-climate of change, processes, and readiness: Development of a new instrument. The Journal of Psychology, 143(6), 559-599. doi. org/10.1080/00223980903218216

Brislin, R. W., Lonner, W. J. ve Thorndike, R. M. (1973). Cross-cultural research methods. New York: John Wiley.

Brown, M. ve Cregan, C. (2008). Organizational change cynicism: The role of employee involvement. $\mathrm{Hu}$ man Resource Management, 47(4), 667-686. doi. org/10.1002/hrm.20239

Cerasoli, C. P., Nicklin, J. M. ve Ford, M. T. (2014). Intrinsic motivation and extrinsic incentives jointly predict performance: A 40-year meta-analysis. Psychological Bulletin, 140(4), 980-1009. doi: 10.1037/a0035661.

Chen, J. ve Wang, L. (2007). Locus of control and the three components of commitment to change. Personality and Individual Differences, 42(3), 503-512. doi.org/10.1016/j.paid.2006.07.025

Choi, M. (2011). Employees' attitudes toward organizational change: A literature review. Human Resource Management, 50(4), 479-500. doi.org/10.1002/ hrm.20434.

Choi, D., Oh, I. S. ve Colbert, A. E. (2015). Understanding organizational commitment: A meta-analytic examination of the roles of the five-factor model of personality and culture. Journal of Applied Psychology, 100 (5), 1542-1567. doi: 10.1037/ ap10000014

Coleman, D. F., Irving, G. P. ve Cooper, C. L. (1999). Another look at the locus of control-organizational commitment relationship: It depends on the form of commitment. Journal of Organizational Behavior, 20(6), 995-1001. doi.org/10.1002/ (SICI)1099-1379(199911)20:6<995::AID-JOB955>3.0.CO;2-3

Cordery, J., Sevastos, P., Mueller, W. ve Parker, S. (1993). Correlates of employee attitudes toward functional flexibility. Human Relations, 46(6), 705-723. doi. org/10.1177/001872679304600602.

Darlington, R. B. ve Hayes, A. F. (2017). Regression analysis and linear models: Concepts, applications, and implementation. New York: The Guilford Press.

Devos, G., Buelens, M. ve Bouckenooghe, D. (2007). Contribution of content, context, and process to understanding openness to organizational change: Two experimental simulation studies. The Journal of Social Psychology, 147(6), 607-630. doi. org/10.3200/SOCP.147.6.607-630
Dunham, R. B., Grube, J. A., Gardner, D. G., Cummings, L. L. ve Pierce, J. L. (1989). The development of an attitude toward change instrument. Washington, DC: Academy of Management Annual Meeting.

Eagly, A.H. ve Chaiken, S. (1998). Attitude structure and function. D.T. Gilbert, S.T. Fiske ve G. Lindsey, (Ed.) Handbook of Social Psychology içinde (269322). Boston, MA: McGraw-Hill.

Eby, L. T., Freeman, D. M., Rush, M. C. ve Lance, C. E. (1999). Motivational bases of affective organizational commitment: A partial test of an integrative theoretical model. Journal of Occupational and Organizational Psychology, 72(4), 463-483. doi. org/10.1348/096317999166798

Elias, S. M. (2009). Employee commitment in times of change: Assessing the importance of attitudes toward organizational change. Journal of Management, 35(1), 37-55. doi.org/10.1177/0149206307308910

Ægisdóttir, S., Gerstein, L. H. ve Çınarbaş, D. C. (2008). Methodological issues in cross-cultural counseling research equivalence, bias, and translations. The Counseling Psychologist, 36(2), 188-219. doi. org/10.1177/0011000007305384

Fedor, D. B., Caldwell, S. ve Herold, D. M. (2006). The effects of organizational changes on employee commitment: A multilevel investigation. Personnel Psychology, 59(1), 1-29.

Fishbein, M. ve Ajzen, I. (1975). Belief, attitude, intention, and behavior. Reading, MA: Addison-Wesley.

Fok, L. Y., Hartman, S. J., Patti, A. L. ve Razek, J. R. (2000). The relationships between equity sensitivity, growth need strength, organizational citizenship behavior, and perceived outcomes in the quality environment: A study of accounting professionals Journal of Social Behavior and Personality, 15(1), 99-120. doi.org/10.1177/1046496408326575

George, J. M. ve Jones, G. R. (2001). Towards a process model of individual change in organizations. Human Relations, 54(4), 419-444. doi. org/10.1177/0018726701544002

Goldberg, L. R. (1992). The development of markers for the Big-Five factor structure. Psychological Assessment, 4(1), 26-42. doi.org/10.1037/1040-3590.4.1.26

Graen, G. B., Scandura, T. A. ve Graen, M. R. (1986). A field experimental test of the moderating effects of growth need strength on productivity. Journal of Applied Psychology, 71(3), 484-491. doi. org/10.1037/0021-9010.71.3.484

Greenhalgh, T., Robert, G., Macfarlane, F., Bate, P. ve Kyriakidou, O. (2004). Diffusion of innovations in service organizations: systematic review and recommendations. Milbank Quarterly, 82(4), 581629. doi: 10.1111/j.0887-378X.2004.00325.x 
Grimm, C. M. ve Smith, K. G. (1991). Research notes and communications management and organizational change: A note on the railroad industry. Strategic Management Journal, 12(7), 557-562. doi. org/10.1002/smj.4250120708

Gürbüz, S. (2019). Sosyal bilimlerde aracı, düzenleyici ve durumsal etki analizleri. Ankara: Seçkin Yayıncılık.

Gürbüz, S., Ayhan, Ö. ve Sert, M. (2014). Örgütsel vatandaşlık davranışı ve örgütsel bağlılık ilişkisi: Türkiye'de yapılan araştırmalar üzerinden bir meta analizi. İş ve İnsan Dergisi, 1(1), 3-19. doi. org/10.18394/iid.22845

Gürbüz, S. ve Şahin, F. (2018). Sosyal bilimlerde araştırma yöntemleri (5. baskı). Ankara: Seçkin Yayıncrlik.

Hackman, J. R. ve Oldham, G. R. (1974). The Job Diagnostic Survey: An instrument for the diagnosis of jobs and the evaluation of job redesign projects (Tech. Rep. No. 4). New Haven, CT: Yale University, Department of Administrative Sciences.

Hackman, J. ve Oldham, G. R. (1980). Work redesign. Reading, MA: Addison-Wesley.

Hall, G. E. ve Hord, S. M. (1987). Change in schools: Facilitating the process. New York, NY: State University of New York Press.

Hayes, A. F. (2018). Introduction to mediation, moderation, and conditional process analysis: A regression-based approach (2. baskl). New York: The Guilford Press.

Hayes, A. F. ve Rockwood, N. J. (2017). Regression-based statistical mediation and moderation analysis in clinical research: Observations, recommendations, and implementation. Behaviour Research and Therapy, 98, 39-57. doi: 10.1016/j. brat.2016.11.001.

Herscovitch, L. ve Meyer, J. P. (2002). Commitment to organizational change: extension of a three-component model. Journal of Applied Psychology, 87(3), 474. doi.org/10.1037/0021-9010.87.3.474

Houkes, I., Janssen, P. P., de Jonge, J. ve Nijhuis, F. J. (2001). Work and individual determinants of intrinsic work motivation, emotional exhaustion, and turnover intention: A multi-sample analysis. International Journal of Stress Management, 8(4), 257283. doi.org/10.1023/A:1017561531748

Hughes, M. (2011). Do 70 per cent of all organizational change initiatives really fail?. Journal of Change Management, 11(4), 451-464. doi: 10.1080/14697017.2011.630506

Isabella, L. A. (1990). Evolving interpretations as a change unfolds: How managers construe key organizational events. Academy of Management Journal, 33(1), 7-41. doi.org/10.2307/256350
Iverson, R. D. (1996). Employee acceptance of organizational change: the role of organizational commitment. International Journal of $\mathrm{Hu}$ man Resource Management, 7(1), 122-149. doi. org/10.1080/09585199600000121

Jöreskog, K. G. (1993). Testing structural equation models. K. A. Bollen ve J. S. Long (Ed.), Testing structural equation models içinde (294-316). Newbury Park, CA: Sage.

Judge, T. A., Thoresen, C. J., Pucik, V. ve Welbourne, T. M. (1999). Managerial coping with organizational change: A dispositional perspective. Journal of Applied Psychology, 84(1), 107-122. doi. org/10.1037/0021-9010.84.1.107

Kartopu, M. ve Gürbüz, S. (2016). Askerî pilotların örgütsel bağlılıklarının, işten ayrılma niyetlerine etkisi: Alternatif iş imkânlarının düzenleyicilik rolü. Savunma Bilimleri Dergisi, 15(1), 79-112.

KHO, (2016). Askeri organizasyonlarda değişim ve dönüşümün yönetimi sempozyumu bildiriler kitabı. Ankara: Kara Harp Okulu Basımevi.

Kouzes, J. M. ve Posner, B. Z. (2002). The leadership challenge (3. baskl). San Francisco: Jossey-Bass.

Kwahk, K. Y. ve Kim, H. W. (2008). Managing readiness in enterprise systems-driven organizational change. Behavior \& Information Technology, 27(1), 7987. doi.org/10.1080/01449290701398475

Kwahk, K. Y. ve Lee, J. N. (2008). The role of readiness for change in ERP implementation: Theoretical bases and empirical validation. Information \& Management, 45(7), 474-481. doi.org/10.1016/j. im.2008.07.002

Lau, C. M. ve Woodman, R. W. (1995). Understanding organizational change: A schematic perspective. Academy of Management Journal, 38(2), 537-554. doi.org/10.5465/256692

Lazarus, R. S. (1990). Theory-based stress measurement. Psychological Inquiry, 1, 3 - 13. doi.org/10.1207/ s15327965pli0101_1

Lazarus, R. S. (2000). Toward better research on stress and coping. American Psychologist, 55(6), $665-$ 673. doi: 10.1037//0003-066X.55.6.665

LePine, J. A., Colquitt, J. A. ve Erez, A. (2000). Adaptability to changing task contexts: Effects of general cognitive ability, conscientiousness, and openness to experience. Personnel Psychology, 53, 563-593. doi/pdf/10.1026/2191-9186/ a000392

Lines, R. (2005). The structure and function of attitudes toward organizational change. Human Resource Development Review, 4(1), 8-32. doi. org/10.1177/1534484304273818

Loher, B. T., Noe, R. A., Moeller, N. L. ve Fitzgerald, 
M. P. (1985). A meta-analysis of the relation of job characteristics to job satisfaction. Journal of Applied Psychology, 70(2), 280-289. doi. org/10.1177/001872677602901204

Madsen, S. R., Miller, D. ve John, C. R. (2005). Readiness for organizational change: Do organizational commitment and social relationships in the workplace make a difference?. Human Resource Development Quarterly, 16(2), 213-233. doi. org/10.1002/hrdq. 1134

Martin, A. J., Jones, E. S. ve Callan, V. J. (2005). The role of psychological climate in facilitating employee adjustment during organizational change. European Journal of Work and Organizational Psychology, 14(3), 263-289. doi. org/10.1080/13594320500141228

Mathieu, J. E. ve Zajac, D. M. (1990). A review and meta-analysis of the antecedents, correlates, and consequences of organizational commitment. Psychological Bulletin, 108(2), 171-194. doi. org/10.1037/0033-2909.108.2.171

McCrae, R. R. ve Costa, P. T. (1986). Personality, coping, and coping effectiveness in an adult sample. Journal of Personality, 54(2), 385-404. doi.or$\mathrm{g} / 10.1111 / \mathrm{j} .1467-6494.1986 . t b 00401 . \mathrm{x}$

Meyer, J. P. ve Allen, N. J. (1991). A three-component conceptualization of organizational commitment. Human Resource Management Review, 1(1), 6189. doi.org/10.1016/1053-4822(91)90011-Z

Meyer, J. P., Allen, N. J. ve Smith, C. A. (1993). Commitment to organizations and occupations: Extension and test of a three-component conceptualization. Journal of Applied Psychology, 78(4), 538. doi. org/10.1037/0021-9010.78.4.538

Miller, J. F. (2002). Motivating people. Executive Excellence, 19(12), 15.

Miller, V. D., Johnson, J. R. ve Grau, J. (1994). Antecedents to willingness to participate in a planned organizational change. Journal of Applied Communication Research, 22(1), 59-80. doi. org/10.1080/00909889409365387

Moon, M. J. (2000). Organizational commitment revisited in new public management: Motivation, organizational culture, sector, and managerial level. Public Performance \& Management Review, 24(2), 177-194. doi: 10.2307/3381267

Moskos, C. C., Williams, J.A. ve Segal D. R. (2000). The postmodern military: Armed forces after the Cold War. New York: Oxford University Press.

Oreg, S. (2003). Resistance to change: Developing an individual differences measure. Journal of Applied Psychology, 88(4), 680-693. doi:10.1037/00219010.88.4.680
Oreg, S. (2006). Personality, context, and resistance to organizational change. European Journal of Work and Organizational Psychology, 15(1), 73-101. doi.org/10.1080/13594320500451247

Öztürk, D. (2016). TSK 2033 dönüşüm çalışmaları: Temel yaklaşımlar. Askeri organizasyonlarda değişim ve dönüşümün yönetimi sempozyumu bildiriler kitabı (53-70). Ankara: Kara Harp Okulu Basımevi.

Penney, L. M., David, E. ve Witt, L. A. (2011). A review of personality and performance: Identifying boundaries, contingencies, and future research directions. Human Resource Management Review, 21(4), 297-310. doi.org/10.1016/j.hrmr.2010.10.005

Piderit, S. K. (2000). Rethinking resistance and recognizing ambivalence: A multidimensional view of attitudes toward an organizational change. Academy of Management Review, 25(4), 783-794. doi. org/10.5465/amr.2000.3707722

Podsakoff, P. M., MacKenzie, S. B. ve Podsakoff, N. P. (2012). Sources of method bias in social science research and recommendations on how to control it. Annual Review of Psychology, 63, 539-569. doi. org/10.1146/annurev-psych-120710-100452

Preacher, K. J., Rucker, D. ve Hayes, A. F. (2007). Addressing moderated mediation hypotheses: Theory, methods, and prescriptions. Multivariate Behavioral Research, 42(1), 185-227. doi. org/10.1080/00273170701341316

Pulakos, E. D., Arad, S., Donovon, M. ve Plamondon, K. E. (2000). Adaptability in the workplace: Development of a taxonomy of adaptive performance. Journal of Applied Psychology, 85, 612-624. doi:10.1037/0021-9010.85.

Reichers, A. E., Wanous, J. P. ve Austin, J. T. (1997). Understanding and managing cynicism about organizational change. The Academy of Management Executive, 11(1), 48-59. doi. org/10.4135/9781483387444.n38

Rucker, D. D., Preacher, K. J., Tormala, Z. L. ve Petty, R. E. (2011). Mediation analysis in social psychology: Current practices and new recommendations. Social and Personality Psychology Compass, 5(6), 359371. doi.org/10.1111/j.1751-9004.2011.00355.x

Rush, M. C., Schoel, W. A. ve Barnard, S. M. (1995). Psychological resiliency in the public sector:" Hardiness" and pressure for change. Journal of Vocational Behavior, 46(1), 17-39. doi.org/10.1006/ jvbe. 1995.1002

Ryan, R. M. ve Deci, E. L. (2000). Self-determination theory and the facilitation of intrinsic motivation, social development, and well-being. American Psychologist, 55(1), 68-78. doi.org/10.1037/0003-066X.55.1.68 
Satana, N. S. (2008). Transformation of the Turkish Military and the path to democracy. $A r$ med Forces \& Society, 34(3), 357-388. doi.or$\mathrm{g} / 10.1177 / 0095327 \mathrm{X} 07302679$

Schneider, B. (1987). The people make the place. Personnel Psychology, 40(3), 437-453. doi.org/10.1111/j.1744-6570.1987.tb00609.x

Schweiger, D. M. ve DeNisi, A. S. (1991). Communication with employees following a merger: A longitudinal field experiment. Academy of Management Journal, 34(1), 110-135. doi. org/10.5465/256304

Sobel, M. E. (1982). Asymptotic confidence intervals for indirect effects in structural equation models. S. Leinhart, (Ed.), Sociological methodology içinde (290-312). San Francisco, CA: Jossey-Bass.

Stanley, D. J., Meyer, J. P. ve Topolnytsky, L. (2005). Employee cynicism and resistance to organizational change. Journal of Business \& Psychology, 19(4), 429-459. doi.org/10.1007/s10869-0054518-2

Sümer, N., Lajunen, T. ve Özkan, T. (2005). Big five personality traits as the distal predictors of road accident involvement. G. Underwood (Ed.) Traffic and transport psychology içinde (215-230). San Diego, CA: Elsevier.

Terry, D. J. ve Jimmieson, N. L. (2003). A stress and coping approach to organizational change: Evidence from three field studies. Australian Psychologist, 38(2), 92-101. doi.org/10.1080/000500603100017 07097

Vakola, M. ve Nikolaou, I. (2005). Attitudes towards organizational change: What is the role of employees' stress and commitment?.Employee Relations, 27(2), 160-174. doi.org/10.1108/01425450510572685

Vakola, M., Tsaousis, I. ve Nikolaou, I. (2004). The role of emotional intelligence and personality variables on attitudes toward organizational change. Journal of Managerial Psychology, 19(2), 88-110. doi. org/10.1108/02683940410526082

Varoglu, A. K. ve Bicaksiz, A. (2005). Volunteering for risk: The culture of the Turkish armed forces. Armed Forces \& Society, 31(4), 583-598. doi.or$\mathrm{g} / 10.1177 / 0095327$ X0503100407

Wanberg, C. R. ve Banas, J. T. (2000). Predictors and outcomes of openness to changes in a reorganizing workplace. Journal of Applied Psychology, 85(1), 132. doi: 10.12691/education-3-6-16

Wanous, J. P., Reichers, A. E. ve Austin, J. T. (2000). Cynicism about organizational change measurement, antecedents, and correlates. Group \& Organization Management, 25(2), 132-153. doi. org/10.1177/1059601100252003
Wasti, S. A. (2002). Affective and continuance commitment to the organization: Test of an integrated model in the Turkish context. International Journal of Intercultural Relations, 26(5), 525-550. doi. org/10.1016/S0147-1767(02)00032-9

Wasti, S. A. (2003). Organizational commitment, turnover intentions and the influence of cultural values. Journal of Occupational and Organizational Psychology, 76(3), 303-321. doi. org/10.1348/096317903769647193

Yousef, D. A. (2000). Organizational commitment and job satisfaction as predictors of attitudes toward organizational change in a non-western setting. Personnel Review, 29(5), 567-592. doi. org/10.1108/00483480010296401

Zhao, X., Lynch, J. G. ve Chen, Q. (2010). Reconsidering Baron and Kenny: Myths and truths about mediation analysis. Journal of Consumer Research, 37, 197-206. doi: 10.1086/651257 


\section{Ek-1. Türkçeye Uyarlanan Ölçek Maddeleri}

\begin{tabular}{|c|c|c|}
\hline No & Ölçek adı & Maddeler \\
\hline 1 & \multirow{11}{*}{$\begin{array}{l}\text { Değişime İlişkin Tutumlar } \\
\text { Ölçeği }\end{array}$} & Değişimden hoşlanmam. (R) \\
\hline 2 & & Yeni fikirleri denemeye yatkınım. \\
\hline 3 & & Değişim, beni hayal kırıklığına uğratır. (R) \\
\hline 4 & & Değişim, daha iyi çalışmama yardımcı olur. \\
\hline 5 & & Yeni fikirleri her zaman desteklerim. \\
\hline 6 & & Değişim, bana heyecan verir. \\
\hline 7 & & Olaylara ve durumlara iliş̧in yeni yaklaşımlar öneririm. \\
\hline 8 & & Değişimlerin çoğu rahatsız edicidir. (R) \\
\hline 9 & & Değişim, genellikle çalıştığım kurumdaki yetersiz koşulların iyileşmesine yardımcı olur. \\
\hline 10 & & Değişimi desteklemek için ne gerekiyorsa yapmaya hazırım. \\
\hline 11 & & Yeni fikirleri denemekten genellikle çekinirim. (R) \\
\hline 1 & \multirow{4}{*}{ İçsel İş Motivasyonu Ölçeği } & Bu işi iyi yaptığım zaman kendime yönelik olumlu değerlendirmelerim artar. \\
\hline 2 & & Bu işi iyi yaptığım zaman büyük bir kişisel tatmin hissi duyarım. \\
\hline 3 & & Bu işte kötü bir performans sergilediğimi anladığımda kendimi kötü ve mutsuz hissederim. \\
\hline 4 & & Hislerim, genel olarak bu işi ne kadar iyi yaptığımdan şu veya bu şekilde etkilenmez. (R) \\
\hline 1 & \multirow{6}{*}{$\begin{array}{c}\text { Gelişim İhtiyacının Gücü } \\
\text { Ölçeği }\end{array}$} & Harekete geçirici ve ilave gayret gerektiren (kişisel sınırları zorlayıcı) bir iş olması. \\
\hline 2 & & İşimde bağımsız bir şekilde düşünebilme ve hareket edebilme imkânı sağlayan bir iş olması. \\
\hline 3 & & Yaptığım işin yeni şeyler öğrenme fırsatı sağlaması. \\
\hline 4 & & Yaptığım işin, yaratıcı ve hayal gücü yüksek olma firsatı sağlaması. \\
\hline 5 & & Yaptığım işin, kişisel gelişim ve iyileştirme firsatı sağlaması. \\
\hline 6 & & Yaptığım işin, değerli şeyleri başarma hissi veriyor olması. \\
\hline
\end{tabular}

Not. R harfi ile belirtilen maddeler ters kodlanmıştır. 


\section{Summary \\ Motivation, Openness to Experience, and Affective Commitment: The Mediating Role of Attitudes towards Change}

\author{
Sait Gürbüz \\ Social Sciences University of Ankara \\ "The snake which cannot cast its skin has to die. \\ As well the minds which are prevented from \\ changing their opinions; they cease to be mind."
}

Friedrich Nietzsche

Drawing from the quote by Nietzsche, the change itself is inevitable, continuous, and furthermore, necessary. Beer and Nohria (2000) posited that $70 \%$ of all change initiatives fail (for counter-arguments see Hughes, 2011). Most of these failures are attributed to the change agents' negligence of the key role played by the individuals within the organization and especially these individuals' attitudes towards change (Armenakis, Harris, \& Mossholder, 1993; George \& Jones, 2001; Greenhalgh, Robert, Macfarlane, Bate, \& Kyriakidou, 2004; Hall \& Hord, 1987; Isabella, 1990; Lau \& Woodman, 1995; Oreg, 2006). If an organization aims its change efforts to be successful, it should not confine itself to focusing only on the organizational-level issues and neglect the individuals who experience the change itself intensively (Elias, 2009). However, most of the research on organizational change has focused on the organizational-level or macro-level phenomena (e.g., Judge, Thoresen, Pucik, \& Welbourne, 1999; Vakola, Tsaousis, \& Nikolaou, 2004) and overlooked the micro-level variables, such as the psychological processes of the individuals and how these processes function together (Elias, 2009; Fedor, Caldwell, \& Herold, 2006; Wanberg \& Banas, 2000). Additionally, employees' attitudes towards change play a crucial role on whether the organizational change initiatives would end in success (Elias, 2009). For the organizational change efforts to be supported by the employees, their attitudes towards change should be improved and directed in the affirmative or desired way (Antoni, 2004).

\section{Theoretical Background}

Rather than attitudes in general, specific attitudes serve as the antecedents of relevant specific behaviors

\author{
Mehmet Emin Bayık \\ Y1ldırım Beyazıt University of Ankara
}

(Eagly \& Chaiken, 1998; Fishbein \& Ajzen, 1975). In the organizational change literature, though limited, the focus has been on the individuals' attitudes towards change (Choi, 2011). Grimm and Smith (1991) found that younger managers were more likely to adapt themselves to changing environmental factors by modifying their plans than were older managers. Therefore, it is expected that the older the person gets, the more negative his/her attitudes towards change would become.

Hypothesis 1a: There will be a negative relationship between age and attitudes towards change.

Iverson (1996) reported a negative relationship between the employees' tenure and their attitudes toward change. Grimm and Smith (1991) observed that managers with lower tenure adapted themselves to the changes more easily than did managers with higher tenure. Thus;

Hypothesis 1b: There will be a negative relationship between tenure and attitudes towards change.

In the organizational change related studies, education level of the employees was found to be positively related to their attitudes towards change, such that the higher the education level, the more positive the attitudes towards change (Iverson, 1996; Vakola et al., 2004). Cordery, Sevastos, Mueller, and Parker (1993) showed that acceptance of change was higher among the employees with higher education than it was among the employees with lower education. Thus;

Hypothesis 1c: Attitudes towards change will differ in accordance with the educational level. Acceptance of change will be higher among the employees with higher levels of education.

Affective commitment is defined as the individuals' emotional attachment to, identification with, and desire to stay with their organization, as well as striving for the good of their organization (Allen \& Meyer, 1990; Kartopu \& Gürbüz, 2016). It was revealed that affective commitment had a positive effect on attitudes towards change (Iverson, 1996; Kwahk \& Kim, 2008; Kwahk \& Lee, 2008; Madsen, Miller \& John, 2005; Yousef, 2000). Moreover, Martin, Jones, and Callan (2005) and Elias

Address for Correspondence: Prof. Sait Gürbüz, Social Sciences University of Ankara, Faculty of Political Sciences, Departments of Business, Ulus-Altındağ / Ankara

E-mail: sait.gurbuz@asbu.edu.tr 
(2009) found that employees' attitudes towards change predicted their affective commitment. Thus;

Hypothesis 2: Attitudes toward change will have a positive relationship with affective commitment.

Intrinsically motivated employees are the ones who continuously and eagerly seek work assignments that help them develop new skills and that give them opportunities for exercising creativity (Amabile, Hill, Hennessey, \& Tighe, 1994). Thus;

Hypothesis 3: Intrinsic work motivation will have a positive relationship with attitudes towards change.

Miller (2002) posits that individuals high in internal motivation deeply commit to their organizations. Mathieu and Zajac (1990) found a correlational relationship between internal motivation and organizational commitment. Eby, Freeman, Rush, and Lance (1999), Moon (2000), and Elias (2009) reported that internally motivated individuals were more affectively committed to their organizations than those that were not. Additionally, Elias (2009) found evidence for the mediator role of attitudes towards change on the relationship between intrinsic work motivation and affective commitment. Thus;

Hypothesis 4: Attitudes towards change will mediate the relationship between intrinsic work motivation and affective commitment.

In an empirical study, it was found that employees with high level of openness to experience were more likely to make rational decisions than were those with low level of openness to experience (LePine, Colquitt, $\&$ Erez, 2000). In terms of organizational change, those highly open to experience were found to be more open to change initiatives, to be more successful at coping with organizational change (Judge et al., 1999), and to have more positive attitudes towards change (Vakola et al., 2004). Thus;

Hypothesis 5: Openness to experience will have a positive relationship with attitudes towards change.

In a meta-analysis of 50 different studies, Choi, Oh, and Colbert (2015) found that all of the Big Five personality factors were positively related to affective commitment. In accordance with the findings of this recent meta-analysis and the empirical findings on the relationship between openness to experience and attitudes towards change, it is expected that attitudes towards change will mediate the relationship between openness to experience and affective commitment.

Hypothesis 6: Attitudes towards change will mediate the relationship between openness to experience and affective commitment.

For the success of any organizational change attempt, there is a high need for individuals with high level of growth need strength (GNS) and for those who see the change efforts as golden opportunities to open up new horizons (Kouzes \& Posner, 2002). GNS, as the extent of the individuals' need for personal development, overlaps with the idea of seeing the organizational change efforts as an opportunity to learn new things (Elias, 2009). Elias (2009) found that GNS has a positive relationship with attitudes towards change. Similarly, Fok, Hartman, Patti, and Razek (2000) observed that low GNS individuals were more resistant to change efforts in terms of job enrichments conducted for adopting total quality management applications. Thus;

Hypothesis 7: Growth need strength will have a positive relationship with attitudes towards change.

High GNS employees will be more committed to their organizations if their organizations offer them personal development opportunities (Elias, 2009). On the other hand, because low GNS employees would perceive the novelties and additional effort requirements brought by the organizational change efforts as a threat or burden for themselves, their affective commitment to their organizations might be affected negatively in accordance with their worsened attitudes towards change (Houkes, Janssen, de Jonge, \& Nijhuis, 2001). Elias (2009) found that employees' attitudes towards change fully mediated the relationship between GNS and affective commitment. Thus;

Hypothesis 8: Attitudes towards change will mediate the relationship between growth need strength and affective commitment.

\section{Method}

\section{Sample}

In the current study, we used convenience sampling technique; and the participants were the officers ( $\mathrm{n}=$ 783 ) in the Turkish Land Forces. Of the 783 participants; $13(1.17 \%)$ were women and $770(\% 98.3)$ were men; $463(\% 59.1)$ had undergraduate degree, 290 (\%37.1) had master's degree, and $30(\% 3.8)$ had PhD. Participants' average age was 37.3 years $(S D=12.7)$ and their average tenure was 14.5 years $(S D=7.9)$.

\section{Measures and Data Collection Procedures}

Attitudes towards Change. Dunham, Grube, Gardner, Cummings, and Pierce's (1989) 18-item Attitudes Towards Change Scale was used to measure participants' attitudes towards change (sample item: "I look forward to changes at work."). The items that loaded on unexpected factors in exploratory factor analysis were eliminated from the scale (i.e., items 1, 2, 3, 5, 11, 16, and 17). The Cronbach's alpha of the scale was calculated as .91 .

Affective Commitment. Participants' affective commitment levels were measured using Meyer, Allen, 
and Smith's (1993) 6-item Affective Commitment Scale (sample item: "I would be very happy to spend the rest of my career with this organization."). The Cronbach's alpha of the scale was calculated as .88 .

Intrinsic Work Motivation. Hackman and Oldham's (1974) 4-item Intrinsic Work Motivation Scale was used to measure participants' intrinsic work motivation (sample item: "I feel a great sense of personal satisfaction when I do this job well."). The Cronbach's alpha of the scale was calculated as .86 .

Openness to Experience. Openness to experience, a factor of the Big Five Model, was measured via the 10-item openness to experience sub-scale of the Big Five Inventory (BFI; Benet-Martinez \& John, 1998). A sample item from the scale is " $\ldots$ am original, come up with new ideas." In order to maintain the factor structure of the scale, the fifth, sixth, and ninth items were eliminated from further analyses. The Cronbach's alpha of the scale was calculated as .81.

Growth Need Strength. Hackman and Oldham's (1980) 6-item Growth Need Strength Scale was used to measure participants' growth need strength (sample item: "Opportunities to learn new things from my work."). The Cronbach's alpha of the scale was calculated as .86.

\section{Results}

SPSS 24 was used for descriptive statistics, correlation, and reliability analyses. The proposed model was tested via path analyses in AMOS 24 program. The correlation between participants' age and attitudes towards change was negative but not statistically significant $(r=-.07 ; p=.09)$. Therefore, Hypothesis 1a was not supported. The correlation between tenure and attitudes towards change $(r=-.18, p<.01)$ was statistically significant. Therefore, Hypothesis $1 \mathrm{~b}$ was supported. One-way analysis of variance (ANOVA) was conducted to figure out whether attitudes towards change differed in accordance with the educational level. The one-way ANOVA results indicated that participants' attitudes towards change statistically differed among the educational levels $\left(\mathrm{F}_{(2,780)}=4.705, p<.01\right)$. As a result, Hypothesis $1 \mathrm{c}$ was supported.

The relationships between the variables other than demographics were analyzed via Structural Equation Modeling (SEM) analyses. The relationships between the variables were analyzed using SEM where attitudes towards change played a mediation role between its antecedents and affective commitment. Because the results of the SEM analysis indicated that the full mediation model offered a poor fit to the dataset $\left[X^{2}(3, \mathrm{~N}=783)\right.$ $=128.356, p>.01, X^{2} / \mathrm{df}=42.785, \mathrm{RMSEA}=.23, \mathrm{CFI}$
$=.89$, SMSR $=.17]$, a modified model was tested by removing the insignificant paths from the previous model (Jöreskog, 1993). The modified model's fit indices provided that the new model demonstrated a good fit to the dataset $\left[X^{2}(2, \mathrm{~N}=783)=3.828, p>.01, X^{2} / \mathrm{df}=1.91\right.$, RMSEA $=.03$, CFI $=.99$, SRMR $=.02]$. In order to figure out whether the fit indices of the modified model were statistically different from the former model, a $X^{2}$ difference test was conducted. The $X^{2}$ difference statistics $\left(\Delta X^{2}=124.528, p<.001\right)$ suggested that the original model and the modified model were different from each other and the difference was statistically significant. As a result, the remaining hypotheses were assessed using the modified model. Because the coefficient of the path from attitudes towards change to affective commitment was found to be positive and statistically significant $(\beta=$ $.09, p<.05)$, Hypothesis 2 was supported. Likewise, the paths from intrinsic work motivation $(\beta=.13, p<.05)$, openness to experience $(\beta=.43, p<.05)$, and growth need strength $(\beta=.22, p<.05)$ to attitudes towards change were all statistically significant, supporting Hypotheses 3,5 , and 7 .

The results of the path analysis with bootstrapping demonstrated that the indirect effects of intrinsic work motivation $(\beta=.011, \% 95 \mathrm{CI}[.003, .024])$, openness to experience $(\beta=.037, \% 95 \mathrm{CI}[.008, .069]$, and growth need strength $(\beta=.019, \% 95 \mathrm{CI}[.005, .040])$ on affective commitment via attitudes towards change were significant, revealing support for Hypotheses 4, 6, and 8.

\section{Discussion}

In the current study, the demographic characteristics of employees as well as their intrinsic work motivation, openness to experience, and growth need strength were taken as hypothetical antecedents of their attitudes towards change; and it was investigated whether employees' attitudes towards change played a mediating role between those antecedents and affective commitment. It was found that the employees' age did not have any effect on their attitudes towards change, whereas their tenure and education level were significantly related to their attitudes towards change. The SEM results demonstrated that openness to experience, intrinsic work motivation, and growth need strength were antecedents of the attitudes towards change, such that individuals with high openness to experience, high intrinsic work motivation, and high growth need strength had more positive attitudes towards change than had those with low openness to change, low intrinsic work motivation, and low growth need strength. Attitudes towards change mediated the relationships of intrinsic work motivation and openness to experience with affective commitment. 
The finding that intrinsic work motivation is an antecedent of attitudes towards change and that it affects those attitudes positively, is consistent with previous findings (Amabile et al., 1994; Elias, 2009; Houkes et al., 2001; Ryan \& Deci, 2000). It can be stated that those employees with high openness to experience have more positive attitudes towards change because these employees enjoy jobs that add to their personal developments by making them set goals (Amabile et al., 1994). The direct and indirect positive relationships between employees' intrinsic work motivation and affective commitment is in line with the previous findings of studies on different samples (Eby et al., 1999; Elias, 2009; Mathieu \& Zajac, 1990; Moon, 2000). Openness to experience, as one of the Big Five personality factors, is associated with intelligence, creativity, comprehension, imagination, culturedness, curiosity, originality, broad-mindedness, and artistically sensitiveness (Barrick \& Mount, 1991; Goldberg, 1992) and was found to have a positive effect on employees' attitudes towards change. The finding that openness to experience plays a role as an antecedent of attitudes towards change is consistent with the findings reported in previous studies with different samples (Judge et al., 1999; LePine et al., 2000; Pulakos, Arad, Donovon, \& Plamondon, 2000; Vakola et al., 2004). Finally, employees' growth need strength was found to be an essential component for the development of positive attitudes towards change, as in the previous studies (Elias, 2009; Fok et al., 2000; Hackman \& Oldham, 1980; Houkes et al., 2001; Loher, Noe, Moeller, \& Fitzgerald 1985).

Individuals' attitudes towards change are of great importance for managers and change agents in assessing the success of the change efforts. If individuals' attitudes towards change are identified as negative, it is the managers' or change agents' duty to minimize those undesirable attitudes (Antoni, 2004). Considering the negative effects of tenure on attitudes towards change, individuals with longer tenure are to be the focal employees targeted in informing and awareness raising activities before, during, and after the organizational change. The applicants who are more open to experience and have higher levels of intrinsic work motivation and growth need strength are suggested to be recruited to the organizations that are in constant change. It is highly suggested that those who are not open to experience and have low intrinsic motivation and growth need strength are spotted and given special attention when preparing employees to organizational change.

The current study has some limitations and offers avenues for future research. First, the data were collected from a single source, via self-report, and in a cross-sectional design, all of which increase the possibility of common method bias (Podsakoff, MacKenzie, \& Podsakoff, 2012). Additionally, the self-report questionnaire might have been answered in a socially desirable way. Future studies may collect data from different sources. Second, rather than rigid or stable personality characteristics, more malleable or trainable personal characteristics can be chosen as the antecedents of attitudes towards change. Those kinds of variables might help the practitioners to manipulate individuals' attitudes towards change more easily. 